\title{
Neolithic population crash in northwest Europe associated with agricultural crisis
}

Sue Colledge ${ }^{1 *}$, James Conolly ${ }^{2}$, Enrico Crema ${ }^{3}$ and Stephen Shennan ${ }^{1}$

\author{
1s.colledge@ucl.ac.uk; s.shennan@ucl.ac.uk; Institute of Archaeology, University College London, London \\ WC1H OPY, UK \\ ${ }^{2}$ jamesconolly@trentu.ca; Department of Anthropology, Trent University, Peterborough, Ontario K9J 7B8, \\ Canada \\ 3 erc62@,cam.ac.uk; McDonald Institute for Archaeological Research, University of Cambridge, Cambridge \\ CB2 3ER, UK

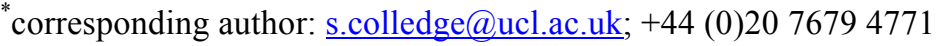

\begin{abstract}
The focus of this paper is the Neolithic of northwest Europe, where a rapid growth in population between $\sim 5950$ and $\sim 5550$ cal yr BP, is followed by a decline that lasted until $\sim 4950$ cal yr BP. The timing of the increase in population density correlates with the local appearance of farming and is attributed to the advantageous effects of agriculture. However, the subsequent population decline has yet to be satisfactorily explained. One possible explanation is the reduction in yields in Neolithic cereal-based agriculture due to worsening climatic conditions. The suggestion of a correlation between Neolithic climate deterioration, agricultural productivity and a decrease in population requires testing for northwestern Europe. Data for our analyses were collected during the Cultural Evolution of Neolithic Europe project. We assess the correlation between agricultural productivity and population densities in the Neolithic of northwest Europe by examining the changing frequencies of crop and weed taxa before, during and after the population 'boom and bust'. We show that the period of population decline is coincidental with a decrease in cereal production linked to a shift towards less fertile soils.
\end{abstract}

Keywords: Neolithic Europe; population change; farming systems; agricultural productivity; sustainability

\section{INTRODUCTION}

The widely recognised increase in central and western European population densities following the local appearance of farming (Collard et al., 2010; Hinz et al., 2012; Shennan et al., 2013; Stevens and Fuller, 2012; Timpson et al., 2014; Whitehouse et al., 2014) is attributed to a suite of advantageous effects of agriculture including the increased dietary availability of a greater complement of carbohydrate-rich plant foods (i.e., in Eurasia the grain crops such as cereals and pulses), reduced mobility, earlier onset of weaning and concomitant higher fertility (Bocquet-Appel, 2008, 2011; Shennan, 2008, 2018). Annual population growth rates for some regions in the early Neolithic are estimated to have been as high as 1.2\% per year (Bocquet-Appel, 2002, figure 5), which in the absence of outmigration would have tripled the size of regional populations in under a century. This is clearly not sustainable and it is thus not surprising that the rapid increase in population did not persist for more than a few centuries before growth rates declined as density-dependent effects on survival and reproduction took hold (Shennan, 2008, 316; Downey et al., 2014, 2016).

Analysis of radiocarbon summed probability distributions (SPDs) provides insight into the chronology and scale of this demographic process across different regions of central and western Europe (for discussions of the method and sampling issues see: Shennan et al., 2013). For example, it has been demonstrated that there was particularly rapid growth of northwest (NW) European populations starting about 5950 cal yr BP and reaching a peak 
approximately four hundred years later (at $\sim 5550$ cal yr BP). Populations then rapidly declined until $\sim 5250 \mathrm{cal}$ yr BP, followed by several centuries of densities far lower than their previous peak (Fig. 1).

The inferred change in population densities from the early to middle Neolithic has been characterised as a 'boom and bust' pattern and is recognisable across most of central and western Europe, although with some regional differences in intensity and periodicity (Collard et al., 2010; Hinz et al., 2012; Shennan, 2013; Shennan et al., 2013; Timpson et al., 2014; Whitehouse et al., 2014). However, the SPDs for Ireland, Scotland and England exhibit trends similar to the overall NW European pattern, with a period of rapid growth at the introduction of agriculture ( $\sim 5950$ cal yr BP) followed by a crash between $\sim 5450$ and $\sim 5250$ cal yr BP (Shennan et al., 2013, figure 3; Timpson et al., 2014, figure 3). Explanations to account for the demographic crash after the initial growth of farming populations have been much debated. When carrying capacities increase due to intensification of food productions and food management strategies, a complex of factors, both cultural and ecological, determine how long the new levels are sustainable. Declines in agricultural productivity as a result of soil exhaustion, erosion, or deleterious climatic changes affecting rainfall and temperature will, in the absence of mitigation strategies, reduce local carrying capacity and lead to population declines. In such scenarios, stability may be dependent upon further intensification of food production systems, increasing the capacity of food storage and distribution of resources, and related changes in social relationships to enable resource management and control. For NW Europe, Hinz et al. $(2012,3340)$ have proposed that "the population decrease ... around $3350 \mathrm{cal}$ BC cannot be explained as easily and its explanation can probably be found in the social realm". Opinions vary as to the role of climate: Shennan et al. (2013) could not find a convincing pan-regional correlation with palaeoclimate proxies; but others, notably Verrill and Tipping (2010), Stevens and Fuller (2012, 2015), Whitehouse et al. (2014), Bevan et al. (2017) and Warden et al. (2017) have presented evidence that links declines, or even abandonment, of Neolithic cereal-based agriculture with climatic deterioration.

The suggestion of a correlation between declines in agricultural productivity and a decrease in population density is compelling, but it remains to be tested at the wider geographic scales from which Neolithic population histories have been reconstructed. Our geographic focus in this paper is NW Europe (Fig. 2) and our assessment of relationships between population levels and agricultural productivity is limited to this region. However, because the 'boomand-bust' pattern is documented more widely across central and western Europe (see previous references) our study is also applicable at a broader scale for the general explanation that demographic declines are correlated with changes in the Neolithic agricultural economy.

\section{Farming systems in Neolithic Europe}

In part based on analogy with ethnographically-observed slash-and-burn agriculture in tropical southeast (SE) Asia, it was long assumed that early Neolithic farming introduced to central and some parts of western Europe in the second half of the $8^{\text {th }}$ millennium BP was based on shifting cultivation (for a comprehensive review of the literature see Bogaard, 2004, 22-28). Shifting cultivation - and the necessity to move to new plots after one to three years to ensure stability in crop yields - gave rise to the concept of migratory farmers who moved across Europe taking with them the domestic crops that were first cultivated in southwest (SW) Asia (Bogaard, 2004, 22, 26). It is an extensive system of production, with low labour input and low returns per unit area, but high returns per capita (van der Veen, 2005, 158, 
table 1), and involves the opening up of small plots in wooded areas by tree felling, followed by burning of the cleared surfaces and cut timbers (Nye and Greenland, 1965, 1-4; Juo and Manu, 1996, 52; Schier et al., 2013, 82). Crops are sown or planted directly in the cleared layer, usually without any prior preparation of the soil, and subsequent growth is enhanced by the nutrient-rich ash that accumulates after burning (Nye and Greenland, 1965, 66-73; Schier, $2009,24)$. Although crop yields are maintained at high levels for the first two to three years, subsequent annual returns decline to such an extent that further cultivation on the same plot becomes unviable due to the rapid depreciation in soil fertility because of the high net nutrient losses that shifting cultivation incurs (Nye and Greenland, 1965; Kleinman et al., 1995, 238; Juo and Manu, 1996, 53-55; Rösch, 2012; Schier et al., 2013, 83-86). Nutrient reserves are restored and soil productivity is improved in the long fallow period after cultivation and cropping (Kleinman et al., 1995, 237; Schier et al., 2013, 80).

Over the last two decades advances in archaeobotanical analysis and re-evaluation of data previously used in support of shifting cultivation has led to the formation of a new model. Based on direct evidence from weed assemblages in crop-rich samples (for detailed discussion see Methods section on Weed ecology) and, more recently, isotope analysis of crop and faunal material (Fraser et al., 2011; Bogaard et al., 2013, 2016), the current consensus is that the early Neolithic farming in central and parts of western Europe, which was almost entirely confined to loess-based soils, was instead founded on a system of intensive cultivation that ensured sustainable practices and occupational permanency (Maier, 1999, 90-91; Bogaard, 2002, 2004, 2005; Jacomet et al., 2004, 399; Bogaard and Jones, 2007, 368; Jacomet, 2009, 54; McClatchie et al., 2014, 213-214). The hypothesis that cultivated soils would have become rapidly depleted of nutrients (thus leading to the adoption of shifting cultivation methods) has been rejected on the basis of field trials in which application of fertilisers (e.g., midden deposits and animal manure) and the use of appropriate field maintenance techniques suggest that sustainable yields can occur whilst continuously cropping (Bogaard, 2002, 2004, 2005). Also, the claimed lack of evidence for long-term occupation of early Neolithic sites in Europe that had been cited in support of transient and shifting cultivation has now been discounted, at least for the Linearbandkeramik (LBK) early Neolithic of central Europe (Bogaard, 2004, 26); some sites, for example Vaihingen in southern Germany, were occupied for hundreds of years (Bogaard et al., 2011). Moreover, compared to tropical slash and burn systems where the maintenance of soil productivity is totally reliant on the 'resting fallow' period because of leaching of nutrients through high rainfall, it is argued that the fertility of intensively cultivated soils recovers more easily in temperate climates, and the greater reliance on domestic mammals in Neolithic Europe, especially cattle, meant that there was a guaranteed supply of manure (Nye and Greenland, 1965, 4; Bogaard, 2004, 26-27; van der Veen, 2005, 157-158).

This system of intensive cultivation is small in spatial scale and the investment of labour produces high returns per unit of land but low returns per capita (Bogaard, 2004, 159; Jones, 2005, 165; van der Veen, 2005, 158, table 1; McClatchie, 2014). In an efficiently functioning intensive system the aim is not only to maintain productivity but also to enhance crop yields by using land management techniques that preserve and improve soil quality (i.e., rather than by expanding the area under cultivation, as in extensive farming systems), so that increased frequency of cropping is viable (Reeves, 1997; McClatchie, 2014, 311). Its success, in terms of long-term sustainability, is reliant not only on the adequate investment of labour and the efficient organisation of seasonal scheduling throughout the annual cultivation cycle, but also on the close interrelationship with small-scale animal husbandry (Bogaard, 2005, 178-179). The benefits of fully integrated 'intensive mixed farming' are clear: the welfare of livestock 
is assured because there is guaranteed year-round provision for their nutritional needs in the form of fodder (crop by-products) and forage (crop stubble), the end-product of which is manure that can be used to fertilise the fields (Bogaard, 2005, 179-180; for references on isotopic analyses and their relevance to reconstructions of past land use, see Fraser et al., 2011; Bogaard et al., 2013). Addition of manure ensures that soil organic matter and nutrients are replaced and losses incurred during cultivation (e.g., tillage, harvesting) are compensated for, and therefore soil productivity is maintained (Bakels, 1997; Isaakidou, 2011; Bogaard, 2013; for discussion of the possible deficiencies in animal manure during the Neolithic, see: Bogaard, 2012, 36-37). The inference being, therefore, that this model of Neolithic agriculture was founded on an intensive system of cultivation that was sustainable (i.e., longlived or permanent) and involved husbandry practices that preserved soil productivity over prolonged crop harvest cycles (Kleinman et al., 1995, 236-237; Bogaard, 2002, 163; Bogaard, 2005, 183; Bogaard and Jones, 2007, 368; Jacomet, 2009, 55; Bogaard et al., 2011, 397; Bogaard et al., 2013, 12593; McClatchie et al., 2014, 213-214).

According to the fixed plot model, cultivation on the same plots of land over long periods was long-lived, therefore maintained populations and precluded the need for frequent relocation. On the basis of evidence derived from archaeobotanical records of weeds of cultivation found in crop-rich samples, small-scale intensive 'garden-type' cultivation was first proposed for the early Neolithic LBK of the central European loess belt and has subsequently been applied more widely to the middle/late Neolithic and to other regions of Europe, e.g., the northwest and the Alpine Foreland in the south (Bogaard, 2002, 2004, 2005; Bogaard and Jones, 2007; Jacomet, 2009, 54; McClatchie et al., 2014). The fixed plot model of sustainable returns and occupational permanency is argued to have characterised central and western Neolithic agriculture, to such an extent that "the practice of intensive cultivation itself was a central expression of Neolithic ideology" (Bogaard, 2004, 169). However, two aspects of this system remain unclear for areas beyond the central loess belt of preferred LBK soils: (1) the long-term (i.e., over several centuries) viability of intensively worked soils of different characteristics; and (2) the relative performance of fixed versus shifting strategies of field management. In fact, given the Neolithic 'boom and bust' population pattern documented by Shennan et al., (2013) and also evidence that post-LBK (middle and late Neolithic) agricultural systems in Europe may have adopted shifting cultivation strategies with long fallow periods (Rösch, 1993; 2012; Schier, 2009; Schier et al., 2013; for alternative viewpoint see Jacomet et al., 2016), it is reasonable to consider the possibility that the system of intensive fixed plot cultivation may not have been sustainable over the very long-term, independently of any hypothesised climate-driven worsening of growing conditions.

\section{Hypotheses}

What was the relationship between the Neolithic agricultural economy and changes in population densities observed between $\sim 5950$ and $\sim 5250$ cal yr BP? Although climate forcing is a distinct possibility (e.g., as recently tested by Bevan et al., 2017), it should also be considered that early Neolithic cultivation practices themselves were detrimental to soil health. We thus consider in some detail the relationship between cultivation and soil degradation to evaluate the possibility that this was a further factor in the decline in agricultural productivity over the period in question. The hypothesis that we develop and test in this paper proposes that the Neolithic population decline was caused by a decrease in the productivity of crop-based agriculture. The alternate hypothesis is that observed regional population crashes were unrelated to agricultural output - e.g., the 'social reasons' alluded to by Hinz et al. (2012). To test the hypothesis, we evaluate the correlation between population 
change, crop use and soil quality for the time period in question. By showing that archaeobotanical data for domestic crop taxa and weeds (e.g., as indicators of field ecologies) change in ways consistent with a reduction in productivity, we aim to strengthen the hypothesis that Neolithic farming practices were a significant factor in the decline, and that this is a reasonable causal explanation for the population crash.

\section{MATERIALS}

The data for this analysis were collated during the Cultural Evolution of Neolithic Europe project (acronym: EUROEVOL http://www.ucl.ac.uk/euroevol), the geographical scope of which is the western half of temperate Europe and the period covered is from 7950 to 3950 cal yr BP (Manning et al., 2015, 2016; data available at: http://discovery.ucl.ac.uk/1469811/). The EUROEVOL database includes archaeobotanical data for 334 sites with 398 phases (for the applied definition of 'phase' see Shennan et al., 2013) that are taken from published reports, in which there are comprehensive lists of plant taxa together with descriptions of criteria used to confirm identifications, and details of sampling (e.g., sample sizes, contexts sampled) and recovery methods (e.g., flotation, wet-sieving, dry sieving, mesh sizes; Colledge, 2016). The data are entered in the database at the level of site or site phase, our rationale being that the project aims are concerned with comparisons at broad regional scales, for example, assessment of intra- and inter-regional processes and not individual site based activities, for which much more detailed sample information would be required.

We assess our hypothesis of a link between population declines and agricultural productivity in the following sections using archaeobotanical data extracted from the published records for 110 phases (from 100 sites) in NW Europe (Britain, Denmark, northern (N) Germany, Ireland, Netherlands, southern (S) Sweden) dating between 5950 and 4700 cal yr BP (Fig. 2). The majority of site records are from Britain and Ireland (45\% and 25\%, respectively) and those from other countries in the study area comprise just under a third of the total $(30 \%)$ Selection of the data was made with reference to review articles by Moffett et al. (1989), Robinson (2003), Jones and Rowley-Conwy (2007), Bishop et al. (2009), Kirleis et al. (2012) and McClatchie et al. (2014) in which regional lists of sites with archaeobotanical records are provided. Many of the sites listed were excluded from our data set because they did not conform to the parameters defined for the analysis; for example, no cereals were present, site dates were too late for our study (or there was insufficient information on dating) or site locations were outside the study area; in addition, several site records could not be accessed because they were in unpublished reports. We also omitted archaeobotanical records for taxa that were waterlogged, on the basis that the rate of survivability of plant materials preserved by waterlogging is disproportionately higher than those preserved by charring and any comparisons between the two are therefore likely to be biased in favour of the greater quantity and diversity of the former type of remains (Colledge and Conolly, 2014). All records of domestic crops and wild species are included in the data set. We used presence data rather than count data in our analyses and to avoid duplication different plant parts of same species or genera were amalgamated so that for each there is a single record only. The rationale for this being that we wanted to compare individual species rather than their constituent plant parts per se.

\section{METHODS}

We test for declines in agricultural productivity between 5950 and $4700 \mathrm{cal}$ yr BP in three ways, by assessing the data set for significant changes in: (1) the representation of cereal 
crops over time that indicate a shift to taxa more tolerant of poorer soils or; (2) changes in weed ecology that indicate a reduction of soil fertility; and (3) changes in site location patterns that a higher incidence on lower ranked soils, all of which are indicative of a deterioration in growing conditions. Each set of data and statistical evaluation is described separately in the sections that follow.

\section{Neolithic agricultural ecology in NW Europe}

\section{Cereal crops}

All crops have defined minimum and maximum abiotic requirements (most crucially in terms of temperature and moisture levels) below or above which viability is compromised, and between which environmental factors that determine healthy growth are the most favourable (referred to as the ecological optimum, Grigg, 1989, 20-22; cf. edaphic optimum, see below). Critical variables, such as precipitation, solar energy, day-length and temperature, are dependent on latitude and in the north at high latitudes, for example, conditions are suboptimal for many crops and as a consequence yields are reduced (Grigg, 1989, 23-24). Thus, if there are declines in soil fertility or extended cold periods with high rainfall we would expect there to be increased use of crops capable of withstanding these unfavourable conditions, at the expense of other less tolerant species. The range and type of crops represented at sites therefore provide an indication of the conditions in which they were cultivated and also the relative yields.

Barley (Hordeum vulgare), oats (Avena sativa) and spelt wheat (Triticum spelta) are better suited to poor growing conditions than many other cereal species. Barley can be grown successfully from the tropics to the Arctic Circle, in areas that experience droughts and also those with frequent frosts (Leonard and Martin, 1963, 483). Its broad ecological scope and tolerance of poor soils makes barley one of the most adaptable crops (Newton et al., 2011, 144; see also: Kirleis et al., 2012, 231; Bogaard et al., 2013, 12591; Styring et al., 2016, 106). Oats are also productive in more extreme environments subject to cold-wet climates and on soils of low fertility (Leonard and Martin, 1963, 547-549; Gill and Vear, 1980, 57; Buerstmayr et al., 2007, 343). Spelt wheat encompasses all the same qualities shown in oats and barley and is well suited to poor growing conditions in areas that are usually considered marginal for cultivation (Bonafaccia et al., 2000, 437). The robust glumes that surround the grains in spikelets of emmer (Triticum diccoccum), einkorn (Triticum monococcum) and spelt wheat serve as protection when crops are susceptible to fungal attack, and particularly in regions with high seasonal rainfall (Hillman, 1981, 1984; Nesbitt and Samuel, 1996; see also Riesen et al., 1986). Einkorn has the added advantage in comparison with many of the other cereal crops in that it does not 'lodge' (i.e., the plants remain upright) after heavy rain (Zaharieva and Monneveux, 2014, 678; Bogaard et al., 2016, 62; see also: Kreuz, 2007, 271, figure 15.11). Free threshing wheats are more exacting in terms of their growth requirements: hexaploid bread wheat (Triticum aestivum) is able to endure colder conditions with frosts than tetraploid durum/macaroni wheat (Triticum durum), which thrives in warmer climates, but is more demanding in terms of edaphic quality and prefers soils with high nutrient levels (Percival, 1974, 207-208; Zohary et al., 2012, 49; see also: Kirleis and Fischer, 2014, S86). In comparison with wheat (in particular bread wheat), barley and oats produce much lower yields but their greater tolerance range affords them obvious advantages in regions with 
unfavourable growing conditions $^{1}$ (Campbell, 2007; DEFRA, 2014, figure 6, table 3; Shewry, 2009).

We tested for changes in cereal crop use over time by counting numbers of phases exhibiting each of the six crop types in five 250 -year date bins from 5950 to 4700 cal yr BP ${ }^{2}$ (see Table 1 for the list of crop types in the data set). We evaluated the differences between phases with Manhattan distance matrixes using the difference between the proportions of the six crops in each date bin $^{1}$. Manhattan distances have few assumptions, work with count data, and may be less sensitive to larger outliers (McCune and Grace, 2002, 55). The Manhattan distance coefficient is scaled from 0 to 1 , with higher numbers indicating greater dissimilarity. The statistical significance of the observed coefficients was established by a permutation test with 1000 simulations from which we calculated Manhattan distance for each of 1000 randomisations. The difference between the observed distances for each of the paired date bins was converted to a standardised (z) which provides a measure of statistical significance Finally, to isolate which crops were contributing to observed differences, we calculated ubiquity (percentage presence) scores by date bin for each crop to identify trends in use over time and also examined the difference between observed and expected crops in each of the five date bins.

\section{Weed ecology}

By studying the ecology of weeds it is possible to obtain information about the conditions of fields in which they grow, such as overall soil quality, and also about the cultivation practices of the crops with which they co-habit, for example tillage, weeding and manuring. To assess likely field conditions and how they changed over time we draw on insights from phytosociology and autoecology. Phytosociology is a hierarchical system for assessing floristic composition and is reliant on the recognition, distinction and classification of 'community units' (Poore, 1955). Autoecology is the study of the behaviour of individual plant species and is based on sets of measured variables that indicate the tolerance range for certain environmental conditions; examples include Ellenberg's indicator values (Ellenberg, 1988, 1991) and FIBS, the functional interpretation of botanical surveys (FIBS, 2015). Both phytosociological and autoecological approaches have been applied in analyses of archaeobotanical assemblages (van Zeist and Palfenier-Vegter, 1981; Wasylikowa, 1981; Jacomet, 1987; M. Jones, 1988; Hillman, 1989; Küster, 1989; Behre, 1991; G. Jones, 1992, 2002; van der Veen, 1992; Karg, 2008; McClatchie et al., 2014). There are, however, methodological problems that to some extent undermine the use of either in the identification of ancient landscapes (van der Veen, 1992, 105-107). A major limitation of phytosociology is the fact that it cannot be assumed vegetation dynamics have remained constant and therefore

\footnotetext{
${ }^{1}$ DEFRA records over the past 15 years show that yields for barley and oats are at least two tonnes per hectare lower than those for bread wheat (e.g., for barley a yield/ha of $77 \%$ in comparison with that of bread wheat, and for oats a yield/ha of $73 \%$ in comparison with that of bread wheat; average yields calculated for 2013 and 2014 , DEFRA, 2014, table 3). Medieval records of crop yields for the period 1270-1429 show similar trends; measured in yield per seed, wheat is the highest at 2.355 , oats are 1.708 ( $76 \%$ relative to wheat yields) and barley is 1.645 (70\% relative to wheat yields; Campbell, 2007, graph 40).

${ }^{2}$ For NW Europe within the period 5950-4700 cal yr BP we have a total of 3,195 14C dates in our database and of these there are only 110 dates (3.4\%) on cereals. All other dates are based on samples of charcoal, non-cereal charred macrofossils and bones.

${ }^{1}$ We calculated the proportion of each crop in each date bin by dividing the number of occurrences of the crop in that bin by the total number of site phases in the bin. For example, barley occurs in 15 out of 24 site phases sampled for the date range 5950-5700 cal yr BP, so has a proportion of 0.63 (refer to table 2D in Results section).
} 
that present-day communities are necessarily an accurate representation of those in the past (Hillman, 1989; Cappers, 1995, 254; Jones, 2002, 185-187). In addition, taphonomic filtering (e.g., resulting from post-harvest cleaning processes, or differential preservation) further diminishes the validity of phytosociology when applied to the study of ancient plant communities. Amalgamation of data, rather the reliance on single, diagnostic species circumvents the problem of incomplete archaeobotanical records. As noted by Jones (2002, 187): “'indicator' species are relatively rare and so, in an already restricted archaeobotanical data set it seems sensible to use information derived from all available species."

As has been common practice in archaeobotanical studies (see van der Veen, 1992, 105), we adopted both phytosociological and autoecological approaches to obtain comparative data on the ecology of wild species (i.e., those represented at sites/site phases with crop-rich samples). We referred to Ellenberg's records for $\sim 3000$ species that were compiled on the basis of field surveys and laboratory experiments carried out in central Europe (Ellenberg, 1988, 665-710). His hierarchical classification system comprises eight main vegetation units (or communities) that include (in order of increasing cover): vegetation of wetlands, frequently disturbed places, heaths and grasslands, and woodlands. Of the eight main vegetation units described in Ellenberg's classification system units 3 and 5 (hereafter U3 and U5) are the most informative about plant communities characteristic of landscapes that are shaped largely under anthropogenic influence; for example, U3 is described as "herbaceous vegetation of frequently disturbed sites" and comprises segetal and ruderal weed communities (including Chenopodietea and Secalietea; Ellenberg, 1988, 667-669), and U5 is described as "heaths and grasslands determined by human and animal activity" and includes pasture and meadow communities (Ellenberg, 1988, 670-672). The individual species data for environmental variables (indicator values) relate to climate and soils, and of these nitrogen and reaction/pH values (classified on scales of one to nine) provide the most useful means of evaluating the relative quality of the soils on which Neolithic crops were grown (Ellenberg, 1988, 675-676). Although Ellenberg's data were based on the central European flora they have been used successfully in other regions of Europe in both modern (e.g., see list of references in Schaffers and Sýkora, 2000, 225) and ancient ecological studies (e.g., in NW Europe: Kirleis, 2002; Karg, 2008; McClatchie et al., 2014; Schepers, 2014).

Data on the life cycles of wild species are also included in our study and are used as a basis for making inferences about the relative intensity of cultivation and the degree of permanence of cultivated fields. Modern survey data of weeds growing in cultivated plots created in recently cleared woodland, and thus replicating shifting cultivation, have been shown to reflect both the ecology of the original wooded area and the intensity of tillage methods used after clearance (e.g., the Hambach Forest experiment, Bogaard, 2002, 160-161). Perennial weeds, and most notably those species common to woodlands, were recorded as being dominant in all plots and those known to grow in more disturbed habitats were prevalent where there had been more invasive tillage; annual species were in a minority in all the experimental plots. The greater proportions of annual species in crop-rich assemblages are thought likely to be an indication of intensive cultivation (Bogaard, 2002, 2004, 2005; Bogaard and Jones, 2007). Comparison of these modern data, specifically the proportions of annuals and perennials, with the life cycles of arable weeds found in archaeobotanical assemblages can, therefore, be used to distinguish between extensive and shifting versus intensive and permanent systems of cultivation.

The analyses included all wild taxa represented in the data set that are identified at the species level (with the exclusion of trees and shrubs); ecological data were assigned to a total 
of 128 species in 67 phases (from 61 sites; NB: not all archaeobotanical site and phase records include wild taxa identified to species). As in previous studies, we have assumed that the wild species in our data set, which occur in archaeological samples together with crops, are weeds (or 'potential weeds') of cultivation that were collected and brought to sites as contaminants of harvests (van der Veen, 1992, 104; McClatchie et al., 2014, 208). For this analysis we counted numbers of species records $(n=334)$ from phases between 5950 and 4700 cal yr BP in the five 250-year bins corresponding to each of Ellenberg's (i) vegetation units U3 and U5; (ii) reaction indicator values in two classes: low (1 to 5, acidic) and high (6 to 9, alkali); (iii) nitrogen level indicators in two classes: low (1 to 5) and high (6 to 9$)^{2}$; and (iv) the counts of phases with perennial and annual weeds (Table 3A). The prediction is that declines in productivity on preferred soils (whether from climate stress or reduced fertility, or a combination of both) will be detectable by temporal trends in vegetation units (i.e., a shift towards an increase in use of pasture lands), reaction and nitrogen values (i.e., an increase in species more tolerant of acidic/nitrogen-poor soils), and by an increase in representation of perennial over annual weed species, which may also have resulted in the movement on to other poor quality soils.

As with crops, we first compared weeds between the 250-year date bins from 5950 to 4700 cal yr BP using Manhattan distance matrixes. We used the proportions of the four variables (vegetation units U3 and U5, perennial and annual weeds, and nitrogen and reaction indicator values) across the five date bins. For each date bin the expected mean and variance of observed coefficients were established by a permutation test with 1000 simulations. We used a z-test to establish the significance of the simulated data against the actual difference between chronological bins for each of the four classes. To establish temporal trends we plotted the ubiquity values corresponding to these ecological data by 250 -year date bin.

\section{Soils}

Good quality soils are defined as those that have sufficient rooting depth (shallow soils lack sufficient moisture and have reduced nutrient levels), good drainage (e.g., a texture that is neither too compact such that water permeability is restricted, nor too loose so drainage is excessive) and are not highly acidic (in acid conditions nitrogen-fixing bacteria are reduced, as are the soil organisms that enhance soil structure and texture) or alkaline (alkali/clay-rich soils have poor structure and limited water absorption capacity; Grigg, 1989, 42-44; Reeves, 1997, 133-135; Manna et al., 2007, 398). As part of a complex cyclical process nutrients are released into the soil through the decay and decomposition of the biomass (e.g., organic materials derived from living or recently living plants and animals; for details of soil nutrient cycling see Nye and Greenland, 1965, chapter 3; Killham, 1994, chapter 4). Any disruption of this closed cycle influences the effectiveness with which the nutrients can be circulated between the biomass and the soil (Grigg, 1989, 44); for example, disequilibrium can result from a lack of adequate compensation for nutrient losses (Nye and Greenland, 1965, 43-46).

The edaphic optimum refers to soil conditions in which a wide variety of crops can be grown and high yields produced without the necessity for any additives in the form of inorganic fertilisers or manures (Grigg, 1989, 41-42; Kleinman et al., 1995, 244). If the specific properties that define this optimum are not met, for example, if soils are highly acidic, are

\footnotetext{
${ }^{2}$ The mid-points of the gradients for both indicator values is 5 ; for nitrogen this relates to species that are: "indicators of sites with average nitrogen availability, seldom found on either poorer or richer soils", and for reaction it relates to species that are: "indicators of fairly acid soils, only occasionally found in more acid or in neutral to slightly alkaline situations" (Ellenberg, 1988, 676).
} 
waterlogged, or have low nutrient status, fewer crops can be grown and yields are diminished. Crops have different growth requirements and tolerances, but most are suited best to deep, well-drained, $\mathrm{pH}$ neutral (or slightly acidic) soils with a good supply of nutrients (Grigg, 1989, 44).

The physical and chemical status of soils is altered as a result of intensive farming. Tillage can lead to erosion of topsoil in which the bulk of the soil organic matter is stored, consequently soil stability, compactability and water holding capacity are adversely affected and nutrient availability is reduced (Kleinman et al., 1995, 244; Shiel, 2013, 13-14; for full descriptions of the effect of tillage on soil quality see Cannell and Hawes, 1994, 252-261). The more invasive the tillage method the greater the negative influence on soil quality; whereas hoeing, raking, digging by hand or scratch ploughing leave crop residues on the soil surface that prevent excessive erosion (Cannell and Hawes, 1994, 249; Doran, 2002, 121 122). Extended periods of continuous cropping also lead to a decline over time in soil organic matter (Reeves, 1997; Doran, 2002, 125).

To obtain direct information on soils we referred to the European Soil Portal - Soil Data and Information Systems website (http://eusoils.jrc.ec.europa.eu/). A total of $278 \mathrm{NW}$ European settlement sites (i.e., all non-habitation burial and ritual sites were excluded) recorded in the EUROEVOL database with a probability $\left(>.05\right.$; inferred from the summed probability of ${ }^{14} \mathrm{C}$ dates) of occupation sometime within the range 5950 to 4700 cal yr BP were plotted on the European soil map and were classified according to the soils on which they are located. A total of 16 major soil groups were included in the analysis (for full list see Table 4). We ranked the soils in terms of their suitability for arable farming with reference to the descriptions given in the JRC Scientific and Technical Report available via the European Soil Portal website (Tóth et al., 2008), in which the soils of the European Union are classified according to a new standard as defined in the World Reference Base for Soil Resources (WRB; FAO, 1998). Our rankings (Class 3: good; Class 2: moderate; Class 1: poor; see Table 4 for ranking criteria) are based on overall soil quality and other factors that either promote or hamper farming practices; soils we considered suitable for arable farming are those described as having high organic matter content and good texture, in contrast to those less appropriate for crop cultivation that are recorded as having poor fertility and drainage and are difficult to work.

We tested for changes in site location in relation to soil quality rank. First, we computed the SPD for each site, normalised the distribution so that the total was equal to one and then calculated the probabilities for each of the five 250-year chronological bins. For each site we retrieved the proportion of different soil types (aggregated by the three classes) within a $5 \mathrm{~km}$ radius and multiplied these with the relative date probability obtained from the SPD. The aggregated value expresses the sum use of each soil class by sites for each of the five temporal bin ranges. Second, to evaluate whether there was a significant change over time in the observed distribution, we used a permutation test (1000 simulations) by randomly reassigning the original SPDs to different site locations. We used a z-test to establish the significance of the observed soil class in each temporal bin against the simulated distribution

\section{RESULTS}

\section{Changes in crop composition}


In the data set we examined barley, emmer and einkorn are the most common species, whereas by comparison free threshing wheat, oats (probably weeds of crop fields in the Neolithic rather than crops per se; McClatchie et al., 2014, 209) and spelt wheat occur less frequently (Table 2A). The results demonstrate that the two periods with the greatest distance from one another are 5450-5200 cal yr BP and 5200-4950 cal yr BP, with a z-score of -2.01 (two-tailed $\mathrm{p}<.05$; Tables $2 \mathrm{~B}$ and $2 \mathrm{C}$ ). The 500 years between 5450 and $4950 \mathrm{cal} \mathrm{yr} \mathrm{BP}$ are thus shown to experience significant changes in the types of crops cultivated in the study region. Moreover, the close similarity between the two earlier phases 5950-5700 cal yr BP and 5700-5450 cal yr BP and the later phase 5200-4950 cal yr BP further emphases the significant change in crop composition in the period 5450-5200 cal yr BP.

Barley remains more-or-less consistent in ubiquity, although it increases from 5950 to 5700 cal yr BP before declining slightly between 5450 and 4950 cal yr BP (Table 2D and Fig. 3). Emmer increases between 5950 and $5450 \mathrm{cal} \mathrm{yr} \mathrm{BP}$ and thereafter decreases in frequency. Einkorn (a crop more commonly found in mainland Europe than in Britain and Ireland; McClatchie et al., 2014, 213) increases dramatically from 4\% to 52\% between 5950 and 5450 cal yr BP, then rapidly declines. Free threshing wheat declines between 5950 and $5700 \mathrm{cal}$ yr BP and then fluctuates until increasing significantly after 5200 cal yr BP. Oats are spelt are difficult to interpret because of low sample numbers, but the former is underrepresented in assemblages between 5450 and $5200 \mathrm{cal} \mathrm{yr} \mathrm{BP}$ whereas spelt is found in greater than expected frequencies between 5700 and 5200 cal yr BP (Table 2E).

\section{Changes in weed ecologies}

The results of the analysis of weed ecologies (Tables 3B-E) are consistent with the crop data and highlight the significant differences in ecological variables between 5450-5200 cal yr BP and 5200-4950 cal BC. The measured differences are all significant at $\mathrm{p}<.05$ (two-tailed) with the exception of the reaction indicator value, which is significant at $\mathrm{p}<.1$ (two-tailed). The results show that there are significant non-random changes over time in the representation of vegetation units U3 and U5, perennial and annual weeds, and nitrogen and reaction indicator values (Table $3 \mathrm{~F}$ ). Comparisons of ubiquity values show that proportions of U3 taxa spike at $5450 \mathrm{cal}$ yr BP and thereafter are replaced by U5 taxa (Table 3G and Fig. 4). The analysis of nitrogen indicator values shows an identical pattern, with low nitrogen values increasing after $5450 \mathrm{cal} \mathrm{yr} \mathrm{BP}$ and dominating by $5200 \mathrm{cal}$ yr BP. Similarly, the incidence of annual species is at a maximum at $5450 \mathrm{cal}$ yr BP and thereafter they are replaced by perennial species. Changes in reaction indicator values are less pronounced but there is a statistically significant trend towards increasing acidity after $5200 \mathrm{cal} \mathrm{yr} \mathrm{BP.}$

\section{Changes in site location according to soil class}

The results demonstrate that the temporal distribution of settlement locations according to soil classes is significantly different from the random model $(\mathrm{p}<.001$; Tables $5 \mathrm{~A}-5 \mathrm{C}$ and Fig. $5)$. When each soil class and temporal bin range is examined for significance it shows that sites on poor (Class 1) soils increase in representation from 5450 to $4950 \mathrm{cal} \mathrm{yr} \mathrm{BP.}$ Conversely, those located on moderate (Class 2) and good soils (Class 3 ) are underrepresented from 5450 cal yr BP onwards.

Note of caution: the limitations of using modern soils for interpreting past conditions 
Any purported correlation between Neolithic site locations and present-day soil classifications that show changes in the status of cultivated land over time (as represented by archaeological assemblages of crops and wild species) requires some justification. Soils are dynamic systems and are continually evolving; their structure and composition is a function of a range of variables including climate, geology, topography, biota, anthropogenic activities (e.g., major land reclamation by drainage during the Medieval period; Honnor and Lane, 2002; Curtis and Campopiano, 2014) and time (Veldkamp, 2005). Modern soil properties are therefore relicts of those that were present in the past. For example, evidence suggests that the imprints of prehistoric land-use are manifest in existing soils because of changes in formation processes that lead to distinctive modifications in soil properties (Macphail et al., 1990; Davidson and Carter, 1998, 2003; Kristiansen, 2001; Guttmann, 2005; Gerlach et al., 2012; Gerlach and Eckmeier, 2012; for examples of the effects on soils of prehistoric land use in NW Europe see: Madsen, 1984; Odgaard, 1992; 1994). Macphail et al. (1990, 65, citing Courty et al., 1989) stress that post depositional reworking of ancient cultivated soils (e.g., by earthworm activity, trampling, mixing) can obscure "the agricultural history from the soil". There are obvious limitations in using modern day soil descriptions to characterise Neolithic productivity without critical evaluation of the evolutionary edaphic processes for each case study (Davidson and Carter, 1998, 827), which is beyond the scope of our present research.

\section{DISCUSSION}

\section{Cereal cultivation in the Neolithic of NW Europe}

Barley, emmer and einkorn are all noted for being able to withstand adverse conditions (see earlier discussions on growth limitations for different cereal species) and their dominance in the data set is likely indicative that many areas covered in our study (e.g., the northernmost sites) were already marginal for arable farming. There are, however, proportional variations in the six crops we tracked that can be matched against Neolithic demographic change, and the most significant of which is a rapid uptake of einkorn from 5700 to $5450 \mathrm{cal} \mathrm{yr} \mathrm{BP} \mathrm{(e.g.,}$ during the period increasing and peak population) suggesting this is when diversification of wheat was required. Moreover, the persistently high ubiquity of barley from 5450 cal yr BP (e.g., during the period of population decline) concurrent with the overall decrease in values for wheat species is consistent with the depreciation in growing conditions (cf. Bevan et al. 2017, figure 4). Our assessment of weed ecologies further highlights the close temporal correlation between a regional population crash in NW Europe and corresponding changes in the growing conditions in crop fields after $5450 \mathrm{cal} \mathrm{yr} \mathrm{BP}$ as shown by the significant increase in U5 taxa (pasture and meadow), perennial weeds and in species tolerant of nitrogen-poor, more acidic soils and we interpret this as representing either in situ soil degradation or the shift to less fertile arable land, both of which are likely to have been correlated with a loss of crop yields. While acknowledging the inherent limitations of the analysis of site location according to soil quality, it is noteworthy that at the coarse scale at which this information is being used the chronological trends in the data are complementary to those for crops and weeds.

In sum, our combined results for analyses of crops, weed ecologies and soils are in accordance and, most significantly, major changes are coincidental with the inferred NW European Neolithic 'boom and bust' patterns in population growth and decline. We have shown that after an earlier period (e.g., from 5950-5450 cal yr BP) of relative stability (e.g., with evidence of comparatively higher yielding crops grown on more fertile arable land) 
when population levels are increasing, there is an apparent decrease in productivity as growing conditions worsened concurrent with a reduction in population (e.g., between 5450 and $4700 \mathrm{cal}$ yr BP). These results therefore support our hypothesis of declining productivity of preferred soils.

\section{Regional comparisons}

\section{Neolithic farming in Britain and Ireland and S Scandinavia and N Germany during the population 'boom'}

The trends we identify in our data are broadly consistent with those reported by others in the different regions of NW Europe, most notably in S Scandinavia and N Germany and in Britain and Ireland. Arable farming at the beginning of the Funnel Beaker culture (date range: 5950-4750 cal yr BP; Fig. 6) in S Scandinavia and N Germany is small-scale and, as indicated in pollen diagrams, there was minimal influence on the environment. It is debated whether or not cultivation was based on slash and burn (/shifting) or intensive methods, those that support the former cite evidence from pollen diagrams of concentrations of charcoal coincidental with anthropogenic indicators of clearance (Andersen, 1992, 171; Robinson, 2007, 367; Hinz et al., 2012, 3333-3334; Sørensen, 2014, table 9), others who question the stratigraphic integrity of these contexts consider shifting cultivation is unlikely (RowleyConwy, 2004, S93). Crop spectra at early Funnel Beaker culture sites show parallels with the combined study results for the equivalent period: emmer and naked barley are the most common crops grown, other less frequently occurring crops include einkorn, free threshing wheat, spelt wheat and hulled barley (Robinson, 2003, 2007, figure 21.2; Kirleis et al., 2012, 233; Sørensen and Karg, 2012, 102, figure 7). Free threshing tetraploid wheat is recorded as being an important crop at several sites and its successful cultivation is thought to have been possible on the nutrient rich soils resulting from clearance by fire of small woodland plots (Kirleis and Fischer, 2014, S91, figure 6).

There is archaeobotanical evidence to suggest that at the advent of farming in Britain and Ireland (date ranges: British early Neolithic: 5950-5350 cal yr BP; Irish early Neolithic: 5950-5550 cal yr BP; Fig. 6) cultivation was intensive and small-scale (Bogaard and Jones, 2007, 368-370; Bishop et al., 2009, 86, citing Barclay, 2003; McClatchie et al., 2014, 212213; Whitehouse et al., 2014, 198-199). The diversity of the crop package is similar across all regions of Britain and Ireland with emmer wheat and barley (hulled and naked varieties) as the major constituents, which is also in accord with our combined results for NW Europe. There are however slight regional differences in terms of which crops are cultivated preferentially. Emmer is the most common crop at Irish early Neolithic sites (i.e., dated to the ENII period) with fewer records for naked and hulled barley, einkorn, free threshing wheat and flax (McClatchie et al., 2014, 208-209; Whitehouse et al., 2014, 189-190; McClatchie et al., 2016). The southern British crop spectrum is comparable to the Irish in terms both of the variety and the frequency of occurrence of the different species (Jones and Rowley-Conwy, 2007, table 23.1). Conversely, in Scotland naked barley appears to have been cultivated preferentially over emmer at more sites although there is variation within the country in the relative proportions of the different crop types (Bishop et al., 2009, 77, table 3, Illus. 3a).

Neolithic farming in Britain and Ireland and S Scandinavia and N Germany during the population 'bust' 
In S Scandinavia and NW Germany from $\sim 5650-5550$ cal yr BP, when population levels are high, land use practices changed and systems of extensive cultivation (e.g., expansive ard cultivation) were adopted in response to the need for enhanced production potential (Hinz et al., 2012, 3333-3334; Kirleis et al., 2012, 223; Sørensen and Karg, 2012, 111; Kirleis and Fischer, 2014, S91). Ard marks have been found at Højensvej, høj 7 on the island of Funen (/Fyn) dated to 5720-5587 cal yr BP, and at the site of Flintbek 3 in Schleswig where the earliest evidence is only slightly later, with dates in the range $\sim 5550-5050$ cal yr BP (Mischka, 2011, 744-747; Sørensen, 2014, table 8). Barley and emmer are the most frequently occurring crops at sites of this period (Kirleis and Fischer, 2014, figure 7).

Reduced fertility in soils under extensive cultivation due to insufficient manuring is thought to have limited the range of crops grown (Kirleis and Fischer, 2014, S92). Our results for the post 'boom' period for Neolithic NW Europe as a whole are indicative of similar trends in land use and growing conditions that we have suggested can be attributed to the declining fertility of arable fields.

When radiocarbon inferred population levels in Britain and Ireland are low (i.e., in the later Neolithic, from $\sim 5350 \mathrm{cal}$ yr BP; date range: Irish middle-late Neolithic: $5550-4450 \mathrm{cal}$ yr BP; Fig. 6), there is evidence for a decline in the intensity of land use and for the regeneration of woodland (Whitehouse et al., 2014, 200, figure 20; Woodbridge et al., 2014, 219). The preferential cultivation in most regions of naked barley coincidental with an increase in the use of edible wild species are thought likely to have been necessary adaptations to cope with deteriorating environmental or social conditions (Bishop et al., 2009, table 3; Verrill and Tipping, 2010, 1019; Stevens and Fuller, 2012, 718; Whitehouse et al., 2014, 200; Woodbridge et al., 2014, 222; Bishop, 2015; Bevan et al., 2017). Correlation at this time between greater use of barley and adverse growing conditions is also consistent with our combined results for NW Europe. Opinions vary as to the extent of the impact on arable farming as a consequence of worsening conditions and some authors suggest there is complete failure resulting in the change to a pastoralist economy supplemented by edible wild plant resources (e.g., as shown by a decline in cereals coincident with an increase in animal remains; Bevan et al., 2017), whereas others who are more equivocal cite clear evidence for the continuation of crop production, albeit at a reduced scale (e.g., in terms of cereal species diversity) in comparison with the early Neolithic (Stevens and Fuller, 2012, 718-719; Whitehouse and Kirleis, 2014, 4; Bishop, 2015; Stevens and Fuller 2015).

\section{Neolithic farming in the Netherlands}

Our results are, however, at odds with regional developments in the Netherlands and we suggest that the disparity in trends between the other two regions in our study is likely due in part to the specific requirements of farming in wetland environments and the limitations these impose on crop cultivation (cf. Out, 2008b). For example, the small-scale semi-agrarian farming of the middle/late Swifterbant (date ranges: middle Swifterbant: 6550-5850 cal yr BP; late Swifterbant: 5850-5350 cal yr BP; Hazendonk group: 5750-5350 cal yr BP; Fig. 6) registers only minimally in the SPDs for the NW European Lowlands (including the Netherlands) and there is no evidence of the dramatic increase in population densities that typifies the introduction of farming in Britain/Ireland and S Scandinavia/N Germany (Timpson et al., 2014, 554, figure 3; see also: Raemaekers, 2003; Cappers and Raemakers, 2008; Out, 2008a, 2008b; Schepers, 2014; Out and Dörfler, 2017). At 4650 cal yr BP, coincidental with the end of the phase of settlement of Vlaardingen group and beginning of the Single Grave Culture (date ranges: Vlaardingen group: 5250-4600 cal yr BP; Single Grave Culture: $4750-4300$ cal yr BP), there is a more pronounced, long-lasting increase in 
inferred population levels that persisted for approximately 300 years (Timpson et al., 2014, figure 3). The impact of farming as witnessed on sites of the Vlaardingen group is when as Raemaekers suggests 'real agrarian settlements' first appeared (Raemaekers, 2003, 745).

\section{Palaeoclimate correlates}

The data we have presented support our hypothesis that a decline in agricultural production is a driver for the identified population crash in NW Europe. The remaining issue is to evaluate whether it is possible to discriminate between either anthropogenic or climatic effects as influential factors in the decline. Our assessment of the current evidence suggests that both were contributory, such that worsening climate coupled with a reduction in soil quality led inevitably to a widespread population crash.

Palaeoclimate records indicate that since the onset of the Holocene the climate was extremely variable (Magny and Haas, 2004; Mayewski et al., 2004). Based on high resolution climate proxy records at least six rapid climate change events have been identified that are thought to have been of sufficient magnitude and extent to have impacted humans and their environments (Magny and Haas, 2004, 428; Mayewski et al., 2004, 244). Pertinent to our study is the fluctuation in climate from 5550-5300 cal yr BP as observed in the higher lake levels at Arbon Bleiche, Lake Constance (Switzerland), and which correlates with the period of declining population densities (Magny and Haas, 2004). This episode of climatic instability is also identified in records for glacial advance and tree limit decline and is characterised by cooler and wetter conditions that are experienced globally in both hemispheres, albeit at differing intensities and scales (Magny and Haas, 2004, 425; Mayewski et al., 2004, 250 and figure 4c; Bevan et al., 2017, figure 3).

The impact of climate on agricultural productivity has been argued in several recent studies that show how colder and wetter climatic conditions after $\sim 5500$ cal yr BP are correlated with a reduction in the quality of growing conditions and evidence of decreases in local Neolithic populations in areas of NW Europe (e.g., Britain and Ireland: Ireland: Verrill and Tipping, 2010; Whitehouse et al., 2014; Bevan et al., 2017; the British mainland: Stevens and Fuller, 2012, 2015; and southern Scandinavia: Hinz, 2015; Warden et al., 2017). For example, in their detailed survey of data from sediment cores in the Baltic Sea Warden et al. (2017) conclude that fluctuations in climate between 6000 and $4000 \mathrm{cal} \mathrm{yr}$ BP were fundamental factors in determining demographic and cultural changes in S Scandinavia. They link ameliorating conditions at the beginning of this period to a dramatic population increase and to the emergence of farming and, most significantly, given the similarity with results we highlight in our study, they state that: "the long term cooling from ca. 5,600 cal. yr BP (most pronounced after 4,500 cal. yr BP) drove a gradual decrease in farming productivity causing a reduction in population size and contributed to a later resurgence of hunter-gatherer-fisher communities" (Warden et al., 2017, 6).

The fact that post-crash population levels remain low for the next several centuries across most of NW Europe, even after the proposed cold/wet climatic episode, reduces the strength of the climate-forcing hypothesis, but is consistent with the hypothesis of a depreciation in soil fertility (Downey et al., 2014, 2016; Bevan et al., 2017, figure 3). Human overexploitation of soils from intensive cultivation during the earlier Neolithic therefore remains in our view a strong, and at least equally compelling explanation for declines in agricultural productivity. 


\section{CONCLUSION}

We have established that agricultural production did decline in the period associated with the middle Neolithic population crash at approximately 5550 cal yr BP in NW Europe. Our data demonstrate persistently high proportions of barley relative to other crop types after $5450 \mathrm{cal}$ yr BP that are consistent with the depreciation in growing conditions; but more significantly data on weed ecology and settlement site locations show an overall decrease in soil fertility of arable fields during this same period. Notably, these changes in agriculture are temporally correlated with declines in population densities that begin at $\sim 5550$ cal yr BP as documented by summed radiocarbon distribution models.

In the specific case of Neolithic agriculture in NW Europe, despite the emergence of a food production system that focussed on small-scale intensive cultivation and which included the application of animal fertilisers to enhance soil quality, we propose that the impact of population growth led to increasing pressure on soils. While the model of intensive fixed-plot cultivation used during the early Neolithic provided high returns and temporarily increased carrying capacity, the data we have presented suggest that in NW Europe these strategies were not sustainable over the longer term (i.e., over four to five centuries). Our results are consistent with the hypothesis that soil degradation increased over the course of the early Neolithic, such that by the middle Neolithic there is a reduction in regional carrying capacities and a widespread change in agricultural strategy towards more extensive and livestock-based approaches (Cramp et al., 2014; Bevan et al., 2017). We propose that because of the long-term stabilisation of populations at well below the densities of the early Neolithic 'boom' period, the role of short term climate deterioration is likely only to have exacerbated a longer-term anthropogenic source of diminishing soil quality.

The consensus amongst historical and agricultural geographers is that farmers were able to adapt practices to changing circumstances, for example to alleviate pressures of overcrowding and subsequent land shortages or to mitigate against losses due to failing harvests, and adopt appropriate strategies for maximising outputs that are not pre-determined but instead are chosen from a range of possible options (Grigg, 1979, 73-74; Grigg, 1980, 8; van der Veen, 2005, 158; McClatchie, 2014, 310-311). Few of these mitigation strategies, however, can be applied without severe consequences for the long-term sustainability of farming systems and agricultural intensification (e.g., increasing inputs per unit area to maintain or increase outputs) can result in severe soil degradation (e.g., Foucher et al., 2014). But the effects of the failure to adapt, or to adopt cultivation systems according to changes in circumstances so as to maintain levels of productivity through intensification are not necessarily manifest in the short term, and as Reeves suggests, the "sustainability of an agricultural system should properly be measured in millenniums [sic], not years or even centuries" (Reeves, 1997, 135). Our work emphasises the value of taking a long-term view of changes in agricultural practices and correlating these with population reconstructions to build an integrated understanding of the relationship between food production, population history and culture change.

\section{ACKNOWLEDGEMENTS}

This research was funded by the European Research Council Advanced Grant \#249390 awarded to Professor Stephen Shennan (UCL) for the EUROEVOL project. We are grateful to Meriel McClatchie for making available the majority of the Irish archaeobotanical data and for her help collating the British and Irish records in the EUROEVOL database. Our thanks 
also to Adrian Timpson who produced Figure 1. Several reviewers made extremely helpful comments and we have amended the text accordingly to address many of the issues they raised; we thank them for their considered and detailed reading of our work.

\section{REFERENCES}

Andersen, S.Th., 1992. Early- and middle-Neolithic agriculture in Denmark: pollen spectra from soils in burial mounds of the Funnel Beaker culture. Journal of European Archaeology $1,153-180$.

Bakels, C.C., 1997. The beginnings of manuring in western Europe. Antiquity 71, 442-445.

Barclay, G.J., 1983. Sites of the third millennium bc to the first millennium ad at North Mains, Strathallan, Perthshire. Proceedings of the Society of Antiquaries of Scotland 113, 122-281.

Behre, K.E., 1991. The ecological interpretation of archaeobotanical data. In: van Zeist, W., Wasylikowa, K., Behre, K.-E. (Eds.), Progress in Old World Palaeoethnobotany. A.A. Balkema, Rotterdam, pp. 81-108.

Bevan, A., Colledge, S., Fuller, D., Fyfe, R., Shennan, S., Stevens, C., 2017. Holocene fluctuations in human population demonstrate repeated links to food production and climate. Proceedings of the National Academy of Sciences DOI: 10.1073/pnas.1709190114

Bishop, R.R., 2015. Summed radiocarbon probability distributions from cereal grains: arable cultivation proxy or the 'archaeology of us'? (a reply to Stevens and Fuller 2015). World Archaeology 47(5), 876-881.

Bishop, R.R., Church, M.J., Rowley-Conwy, P.A., 2009. Cereals, fruits and nuts in the Scottish Neolithic. Proceedings of the Society of Antiquaries of Scotland 139, 47-103.

Bocquet-Appel, J.-P., 2002. Palaeoanthropological traces of a Neolithic demographic transition. Current Anthropology 43, 638-650.

Bocquet-Appel, J.-P., 2008. Explaining the Neolithic Demographic Transition. In: BocquetAppel, J.-P., Bar-Yosef, O. (Eds.), The Neolithic Demographic Transition and its Consequences. Springer, Netherlands, pp. 35-55.

Bocquet-Appel, J.-P., 2011. The Agricultural Demographic Transition During and After the Agriculture Inventions. Current Anthropology 52(S4), S497-S510.

Bogaard, A., 2002. Questioning the relevance of shifting cultivation to Neolithic farming in the loess belt of Europe: evidence from the Hambach Forest experiment. Vegetation History and Archaeobotany 11, 155-168.

Bogaard, A., 2004. Neolithic Farming in Central Europe. An archaeobotanical study of crop husbandry practices. Routledge, London.

Bogaard, A., 2005. 'Garden agriculture' and the nature of early farming in Europe and the Near East. World Archaeology 37(2), 177-196. 
Bogaard, A., 2012. Middening and Manuring in Neolithic Europe: Issues of Plausibility, Intensity and Archaeological Method. In: Jones, R. (Ed.), Manure Matters: Historical, Archaeological and Ethnographic Perspectives. Ashgate Publishing Ltd., Farnham, pp. 25-39.

Bogaard, A., Jones, G., 2007. Neolithic farming in Britain and central Europe: contrast or continuity? In: Whittle, A., Cummings, V. (Eds.), Going over: the Mesolithic-Neolithic transition in north-west Europe. British Academy, London, pp. 357-375.

Bogaard, A., Krause, R., Strien, H.-C., 2011. Towards a social geography of cultivation and plant use in an early farming community: Vaihingen an der Enz, south-west Germany. Antiquity 85, 395-416.

Bogaard, A., Fraser, R.A., Heaton, T.H.E., Wallace, M., Vaiglova, P., Charles, M., Jones, G., Evershed, R.P., Styring, A.K., Andersen, N.H., Arbogast, R.-M., Bartosiewicz, L., Gardeisen, A., Kanstrup, M., Maier, U., Marinova, E., Ninov, L., Schäfer, M., Stephan, E., 2013. Crop manuring and intensive land management by Europe's first farmers. Proceedings of the National Academy of Sciences 110 (31), 12589-12594.

Bogaard, A., Hodgson, J., Nitsch, E., Jones, G., Styring, A., Diffey, C., Pouncett, J., Herbig, C., Charles, M., Ertuğ, F., Tugay, O., Filipovic, D., Fraser, R. 2016. Combining functional weed ecology and crop stable isotope ratios to identify cultivation intensity: a comparison of cereal production regimes in Haute Provence, France and Asturias, Spain. Vegetation History and Archaeobotany 25, 57-73.

Bonafaccia, G., Galli, V., Francisci, R., Mair, V., Skrabanja, V., Kreft, I., 2000.

Characteristics of spelt wheat products and nutritional value of spelt wheat-based bread. Food Chemistry 68, 437-441.

Buerstmayr, H., Krenn, N., Stephan, U., Grausgruber, H., Zechner, E., 2007. Agronomic performance and quality of oat (Avena sativa L.) genotypes of worldwide origin produced under Central European growing conditions. Field Crops Research 101, 343-351.

Campbell, B.M.S., 2007. Three centuries of English crops yields, 1211-1491. http://www.cropyields.ac.uk [Accessed 25.10.2017].

Cannell, R.Q., Hawes, J.D., 1994. Trends in tillage practices in relation to sustainable crop production with special reference to temperate climates. Soil \& Tillage Research 30, 245282.

Cappers, R.T.J., 1995. A Palaeoecological model for the interpretation of wild plant species. Vegetation History and Archaeobotany 4, 249-257.

Cappers R.T.J., Raemakers, D.C.M., 2008. Cereal cultivation at Swifterbant? Neolithic wetland farming in the North European Plain. Current Anthropology 49(3), 385-402.

Collard, M., Edinborough, K., Shennan, S., Thomas, M.G., 2010. Radiocarbon evidence indicates that migrants introduced farming to Britain. Journal of Archaeological Science 37, 866-870. 
Colledge, S., 2016. The Cultural Evolution of Neolithic Europe. EUROEVOL Dataset 3: Archaeobotanical Data. Journal of Open Archaeology Data 5, p.e1. DOI: 10.5334/joad.42

Colledge, S., Conolly, J., 2014. Wild plant use in European Neolithic subsistence economies: a formal assessment of preservation bias in archaeobotanical assemblages and the implications for understanding changes in plant diet breadth. Quaternary Science Reviews 101, 193-206.

Courty, M. A., Goldberg, P., Macphail, R. I., 1989. Soils and Micromorphology in Archaeology. Cambridge University Press, Cambridge.

Cramp, L.J.E., Jones, J., Sheridan, A., Smyth, J., Whelton, H., Mulville, J., Sharples, N., Evershed, R.P., 2014. Immediate replacement of fishing with dairying by the earliest farmers of the northeast Atlantic archipelagos. Proceedings of the Royal Society B (Biological Sciences) 281. DOI: 10.1098/rspb.2013.2372

Curtis, D.R., Campopiano, M., 2014. Medieval land reclamation and the creation of new societies: comparing Holland and the Po Valley, c.800-c.1500. Journal of Historical Geography 44, 93-108

Davidson, D.D., Carter, S.P., 1998. Micromorphological Evidence of Past Agricultural Practices in Cultivated Soils: The Impact of a Traditional Agricultural System on Soils in Papa Stour, Shetland. Journal of Archaeological Science 25, 827-838.

Davidson, D.D., Carter, S.P., 2003. Soils and their evolution. In: Edwards, K.J., Ralston, I.B.M. (Eds.), Scotland after the Ice Age: Environment, Archaeology and History 8000 BC AD 1000. Edinburgh University Press, Edinburgh, pp. 45-62.

DEFRA Farming statistics: Provisional crop areas, yields and livestock populations at June 2014, United Kingdom [Published 16 October 2014] https://www.gov.uk/government/statistics/farming-statistics-provisional-crop-areas-yieldsand-livestock-populations-at-1-june-2014-uk [Accessed 12.12.2014].

Doran, J.W., 2002. Soil health and global sustainability: translating science into practice. Agriculture, Ecosystems and Environment 88, 119-127.

Downey, S.S., Bocaege, E., Kerig, T., Edinborough, K., Shennan, S., 2014. The neolithic demographic transition in Europe: correlation with juvenility index supports interpretation of the summed calibrated radiocarbon date probability distribution (SCDPD) as a valid demographic proxy. PLoS One 9 (8), e105730. DOI: 10.1371/journal.pone.0105730

Downey, S., Haas Jr., W.R., Shennan, S.J. 2016. European Neolithic societies showed early warning signals of population collapse. Proceedings of the National Academy of Sciences USA 113, 9751-9756.

Ellenberg, H., 1988. Vegetation History of Central Europe (translated by Gordon K. Strutt), 4th Edition. Cambridge University Press, Cambridge. 
Ellenberg, H., 1991. Zeigerwerte der Gefäßpflanzen (ohne Rubus). In: Ellenberg, H., Weber, H.E., Düll, R., Wirth, V., Werner, W., Paulißen, D., Zeigerwerte van Pflanzen in Mitteleuropa. Scripta Geobotanica 18, 9-166.

FAO 1998. World reference base for soil resources. World Soil Resources Report 84. Food and Agriculture Organization of the United Nations, Rome.

http://www.fao.org/docrep/W8594E/W8594E00.htm [Accessed 12.12.2014].

FIBS (Functional Interpretation of Botanical Surveys) 2015. Identifying ancient land use through the functional ecology of crop weeds.

http://www.shef.ac.uk/archaeology/research/fibs. [Accessed 09.08.2015].

Foucher, A., Salvador-Blanes, S., Evrard, O., Simonneau, A., Chapron, E., Courp, T., Cerdan, O., Lefèvre, I., Adriaensen, H., Lecompte, F., Desmet, M., 2014. Increase in soil erosion after agricultural intensification: evidence from a lowland basin in France. Anthropocene 7, 30-41.

Fraser, R.A., Bogaard, A., Heaton, T., Charles, M., Jones, G., Christensen, B.T., Halstead, P., Merbch, I., Poulton, P.R., Sparkes, D., Styring, A.K., 2011. Manuring and stable nitrogen isotope ratios in cereals and pulses: towards a new archaeobotanical approach to the inference of land use and dietary practices. Journal of Archaeological Science 38(10), 2790-2804

Gerlach, R., Eckmeier, E., 2012. Prehistoric land use and its impact on soil formation since early Neolithic. Examples from the Lower Rhine Area. eTopoi Special Volume 3, pp. 11-16.

Gerlach, R., Fischer, P., Eckmeier, E., Hilgers, A., 2012. Buried dark soil horizons and archaeological features in the Neolithic settlement region of the lower Rhine area, NW Germany: Formation, geochemistry and chronostratigraphy. Quaternary International 265, 191-204.

Gill, N.T., Vear, K.C., 1980. Agricultural Botany. 2. Monocotyledonous Crops. 3rd Edition (Revised by K.C. Vear and D.J. Barnard) Duckworth, London.

Grigg, D., 1979. Ester Boserup's theory of agrarian change: a critical review. Progress in Human Geography 3, 64-84.

Grigg, D.B., 1980. Population growth and agrarian change: an historical perspective. Cambridge University Press, Cambridge.

Grigg, D., 1989. An introduction to agricultural geography. 2nd Edition. Routledge, London.

Guttmann, E.B.A., 2005. Midden cultivation in prehistoric Britain: arable crops in gardens. World Archaeology 37(2), 224-239.

Hillman, G.C., 1981. Reconstructing crop husbandry practices from charred remains of crops. In: Mercer, R.J. (Ed.), Farming Practice in British Prehistory. Edinburgh University Press, Edinburgh, pp. 123-162.

Hillman, G.C., 1984. Interpretation of archaeological plant remains: the application of ethnographic models from Turkey. In: van Zeist, W., Casparie, W.A. (Eds.), Plants and 
Ancient Man, Studies in Palaeoethnobotany. Proceedings of the Sixth Symposium of the International Work Group for Palaeoethnobotany, Groningen, 30 May-3 June 1983. A.A. Balkema, Rotterdam, pp. 1-42.

Hillman, G., 1989. Phytosociology and Ancient Weed Floras: Taking Account of Taphonomy and Changes in Cultivation Methods. In: Harris, D.R., Thomas, K.D. (Eds.), Modelling ecological change. Institute of Archaeology, University College, London, pp. 27-40.

Hinz, M., 2015. Growth and decline? Population dynamics of Funnel Beaker societies in the $4^{\text {th }}$ millennium BC. In: Brink, K., Hydén, S., Jennbert, K., Olausson, D. S. (Eds.), Neolithic diversities: Perspectives from a conference in Lund, Sweden. Acta archaeologica Lundensia. Series in $8^{\circ}$; No. $65,43-51$.

Hinz, H., Feeser, I., Sjögren, K.-G., Müller, J., 2012. Demography and the intensity of cultural activities: an evaluation of Funnel Beaker Societies (4200-2800 cal BC). Journal of Archaeological Science 39, 3331-3340.

Honnor, J., Lane, T., 2002. Archaeology, arable landscapes and drainage in the Fenland of Eastern England. Oxford Archaeology. Archaeological Project Services. Report no. 27/02, appendix Jiv.

Isaakidou, V., 2011. Farming regimes in Neolithic Europe: gardening with cows and other models. In: Hadjikoumis, A., Robinson, E., Viner, S. (Eds.), The Dynamics of Neolithisation in Europe. Studies in honour of Andrew Sherratt. Oxbow books, Oxford, pp. 90-112.

Jacomet, S., 1987. Ackerbau, Sammelwirtschaft und Umwelt der Egolzwiler- und CortaillodSiedlungen auf dem Kleinen Hafner in Zürich.Ergebnisse samenanalytischer Untersuchungen. In: Suter, P.J., Zürich "Kleiner Hafner": Tauchgrabungen, 1981-1984. Berichte Zürcher Denkmalpflege. Monographien; 3: Kommissionsverlag O. Füssli, Zürich, pp. 144-166.

Jacomet, S., 2009. Plant economy and village life in Neolithic lake dwellings at the time of the Alpine Iceman. Vegetation History and Archaebotany 18, 47-59.

Jacomet, S., Leuzinger, U., Schibler, J. (Eds.), 2004. Die jungsteinzeitliche Seeufersiedlung Arbon Bleiche 3. Umwelt und Wirtschaft, Archäologie im Thurgau, vol. 12. Frauenfeld, Dept. für Erziehung und Kultur des Kantons Thurgau.

Jacomet, S., Ebersbach, R., Akeret, Ö., Antolin, F., Baum, T., Bogaard, A., Brombacher, C., Bleicher, N.K., Heitz-Weniger, A., Hüster-Plogmann, H., Gross, E., Kühn, M., Rentzel, P., Steiner, B.L., Wick, L., Schibler, J.M., 2016. On-site data cast doubt on the hypothesis of shifting cultivation in the late Neolithic (c. 4300-2400 cal. BC): Landscape management as an alternative paradigm. The Holocene 26(11), 1858-1874.

Jones, G., 1992. Weed phytosociology and crop husbandry: identifying a contrast between ancient and modern practice. In: Pals, J.P., Buurman, J., van der Veen, M. (Eds.), Festschrift for Professor van Zeist. Review of Palaeobotany and Palynology 73, 133-143.

Jones, G., 2002. Weed ecology as a method for the archaeobotanical recognition of crop husbandry practices. Acta Palaeobotanica 42(2), 185-193. 
Jones, G., 2005. Garden cultivation of staple crops and its implications for settlement location and continuity. World Archaeology 37(2), 164-176.

Jones, G., Rowley-Conwy, P., 2007. On the importance of cereal cultivation in the British Neolithic. In: Colledge, S., Conolly, J. (Eds.), The Origins and Spread of Domestic Plants in Southwest Asia and Europe. Left Coast Press, Walnut Creek, California, pp. 391-419.

Jones, M., 1988. The phytosociology of early arable weed communities with special reference to southern England. In: Küster, H. (Ed.), Der prähistorische Mensch und siene Umwelt. Forschungen und Berichte zur Vor- und Frühgeschichte in Baden-Württenburg 31, Stuttgart, pp. 43-51.

Juo, A.S.R., Manu, A., 1996. Chemical dynamics in slash-and-burn agriculture. Agriculture, Ecosystems and Environment 58, 49-60.

Karg, S., 2008. Direct evidence of heathland management in the early Bronze Age $\left(14^{\text {th }}\right.$ century B.C.) from the grave-mound Skelhøj in western Denmark. Vegetation History and Archaeobotany 17, 41-49.

Killham, K., 1994. Soil Ecology. Cambridge, Cambridge University Press.

Kirleis, W., 2002. Vegetationsgeschichtliche und archäobotanische Untersuchungen zur Landwirtschaft und Umwelt im Bereich der prähistorischen Siedlungen bei Rullstorf, Ldkr. Lüneburg. Dissertation zur Erlangung des Doktorgrades der MathematischNaturwissenschaftlichen Fakultäten der Georg-August-Universität zu Göttingen.

Kirleis, W., Klooß, S., Kroll, H., Müller, J., 2012. Crop growing and gathering in the northern German Neolithic: a review supplemented by new results. Vegetation History and Archaeobotany 21, 221-242.

Kirleis, W., Fischer, E., 2014. Neolithic cultivation of tetraploid free threshing wheat in Denmark and Northern Germany: implications for crop diversity and societal dynamics of the Funnel Beaker Culture. Vegetation History and Archaeobotany 23 (Suppl. 1), S81-S96).

Klassen, L., 2005. Zur Bedeutung von Getreide in der Einzelgrabkultur Jütlands. http://www.jungsteinsite.uni-kiel.de/pdf/2005_klassen_web.pdf [Accessed 22.01.13].

Kleinman, P.J.A., Pimentel, D., Bryant, R.B., 1995. The ecological sustainability of slashand-burn agriculture. Agriculture, Ecosystems and Environment 52, 235-249.

Kreuz, A., 2007. Archaeobotanical perspectives on the beginning of agriculture north of the Alps. In: Colledge, S., Conolly, J. (Eds.), The Origins and Spread of Domestic Plants in Southwest Asia and Europe. UCL Institute of Archaeology and Left Coast Press, California, pp. 259-294.

Kristiansen, S.M., 2001. Present-day soil distribution explained by prehistoric land-use: Podzol-Arenosol variation in ancient woodland in Denmark. Geoderma 103, 273-289.

Küster, H., 1989. Phytosociology and archaeobotany. In: Harris, D.R., Thomas, K.D. (Eds.), 
Modelling ecological change. Institute of Archaeology, University College, London, pp. 1726.

Leonard, W.H., Martin, J.H., 1963. Cereal Crops. The Macmillan Company, New York.

Macphail, R.I., Courty, M.A., Gebhardt, A., 1990. Micromorphological evidence for early agriculture in North-West Europe. World Archaeology 22(1), 53-69.

Madsen, H.B., 1984. Clay Migration and Podzolisation in a Danish Soil. Geografisk Tidsskrift-Danish Journal of Geography 84(1), 6-9.

Magny, M., Haas, J.N. 2004. A major widespread climatic change around 5300 cal. yr BP at the time of the Alpine Iceman. Journal of Quaternary Science 19(5), 423-430.

Maier, U., 1999. Agricultural activities and land use in a Neolithic village around 3900 B.C.: Hornstaad Hörnle IA, Lake Constance, Germany. Vegetation History and Archaeobotany 8, 87-94.

Manna, M.C., Swarup, A., Wanjari, R.H., Mishra, B., Shahi, D.K., 2007. Long-term fertilization, manure and limiting effects on soil organic matter and crop yields. Soil \& Tillage Research 94, 397-409.

Manning, K., Timpson, A., Colledge, S., Crema, E., Edinborough, K., Kerig, T., Shennan, S., 2014. The chronology of culture: a comparative assessment of European dating approaches. Antiquity 88, 1065-1080.

Manning, K., Timpson, A., Colledge, S., Crema, E., Shennan, S., 2015. The Cultural Evolution of Neolithic Europe. EUROEVOL Dataset. http://discovery.ucl.ac.uk/1469811/

Manning, K, Colledge, S, Crema, E, Shennan, S., Timpson, A., 2016. The Cultural Evolution of Neolithic Europe. EUROEVOL Dataset 1: Sites, Phases and Radiocarbon Data. Journal of Open Archaeology Data 5, p.e2. DOI: 10.5334/joad.40

Mayewski, P.A., Rohling, E.E., Stager, J.C., Karlén, W., Maasch, K.A., Meeker, L.D., Meyerson, E.A., Gasse, F., van Kreveld, S., Holmgren, K., Lee-Thorp, J., Rosqvist, G., Rack, F., Staubwasser, M., Schneider, R.R., Steig, E.J., 2004. Holocene climate variability. Quaternary Research 62, 243-255.

McClatchie, M., 2014. Archaeobotany of Agricultural Intensification. In: Smith, C. (Ed.), Encyclopedia of Global Archaeology. Springer, New York, pp. 310-318.

McClatchie, M., Bogaard, A., Colledge, S., Whitehouse, N.J., Schulting, R.J., Barratt, P., McLaughlin, T.R., 2014. Neolithic farming in north-western Europe: archaeobotanical evidence from Ireland. Journal of Archaeological Science 51, 206-215.

McClatchie, M., Bogaard, A., Colledge, S., Whitehouse, N.J., Schulting, R.J., Barratt, P., McLaughlin, T.R., 2016. Farming and foraging in Neolithic Ireland: an archaeobotanical perspective. Antiquity 90, 302-318. 
McCune, B., Grace, J.B., 2002. Analysis of Ecological Communities. MjM Software, Gleneden Beach, Oregon, USA

Mischka, D., 2011. The Neolithic burial sequence at Flintbek LA 3, north Germany, and its cart tracks: a precise chronology. Antiquity 85, 742-758.

Moffett, L., Robinson, M.A., Straker. V., 1989. Cereals, fruits and nuts: charred plant remains from Neolithic sites in England and Wales and the Neolithic economy. In: Milles, A., Williams, D., Gardner, N. (Eds.), The beginnings of agriculture. (British Archaeological Reports International Series S496), BAR, Oxford, pp 243-261.

Nesbitt, M., Samuel, D., 1996. From staple crop to extinction? The archaeology and history of the hulled wheats. In: Padulosi, S., Hammer, K., Heller, J. (Eds.), Hulled Wheats.

Promoting the Conservation and Use of Underutilized and Neglected Crops. IPGRI, Rome, pp. 41-100.

Newton, A.C., Flavell, A.J., George, T.S., Leat, P., Mullholland, B., Ramsay, L., RevoredoGiha, C., Russell, J., Steffenson, B.J., Swanston, J.S., Thomas, W.T.B., Waugh, R., White, P.J., Bingham, I.J., 2011. Crops that feed the world 4. Barley: a resilient crop? Strengths and weaknesses in the context of food security. Food Security 3, 141-178.

Nye, P.H., Greenland, D.J., 1965. The soil under shifting cultivation. Technical Communications No. 51. Commonwealth Bureau of Soils, Harpenden. Jarrold \& Sons Ltd., Norwich.

Odgaard, B.V., 1992. The fire history of Danish heathland areas as reflected by pollen and charred particles in lake sediments. The Holocene 2(3), 218-226.

Odgaard, B.V., 1994. The Holocene vegetation history of northern West Jutland, Denmark. Opera Botanica 123, 5-171.

Out, W.A., 2008a. Neolithisation at the site of Brandwijk-Kerkof, the Netherlands: natural vegetation, human impact and plant food subsistence. Vegetation History and Archaeobotany $17,25-39$.

Out, W.A., 2008b. Growing habits? Delayed introduction of crop cultivation at marginal Neolithic wetland sites. Vegetation History and Archaeobotany 17 (Suppl. 1), S131-S138.

Out, W.A., Dörfler, W., 2017. The best of both worlds: Human impact and plant subsistence at the Middle and Late Neolithic semi-agricultural site of Hekelingen III (2900-2500 BC). Quaternary International 436B. 41-63.

Percival, J., 1974. The Wheat Plant. Duckworth \& Co. Ltd., London.

Poore, M.E.D., 1955. The Use of Phytosociological Methods in Ecological Investigations: I. The Braun-Blanquet System. The Journal of Ecology 43(1), 226-244.

Raemaekers, D., 2003. Cutting a long story short? The process of neolithization in the Dutch delta re-examined. Antiquity 77, 740-748. 
Raemakers, D.C.M., Paulien de Roever, J., 2010. The Swifterbant pottery tradition (50003400 BC): matters of fact and matters of interest. In, Vanmontfort, B., Louwe Kooijmans, L., Amkreutz, L., Verhart, L. (Eds.), Pots, Farmers and Foragers. Pottery traditions and social interactions in the earliest Neolithic of the Lower Rhine Area. Archaeological Studies Leiden University 20, Leiden University Press, pp.135-149.

Reeves, D.W., 1997. The role of soil organic matter in maintaining soil quality in continuous cropping systems. Soil \& Tillage Research 43, 131-167.

Riesen, Th., Winzeler, H., Rüegger, A., Fried, P.M., 1986. The effect of glumes on fungal infection of germinating seed of spelt (Triticum spelta L.) in comparison to wheat (Triticum aestivum L.) Journal of Phytopathology 115(4), 318-324.

Robinson, D.E., 2003. Neolithic and Bronze Age agriculture in Southern Scandinavia recent archaeobotanical evidence from Denmark. Environmental Archaeology 8, 145-165.

Robinson, D.E., 2007. Exploitation of plant resources in the Mesolithic and Neolithic of southern Scandinavia: from gathering to harvesting. In: Colledge, S., Conolly, J. (Eds.), The Origins and Spread of Domestic Plants in Southwest Asia and Europe. UCL Institute of Archaeology and Left Coast Press, California, pp. 359-374.

Rösch, M., 1993. Prehistoric land use as recorded in a lake-shore core at Lake Constance. Vegetation History and Archaeobotany 2, 213-232.

Rösch, M., 2012. Forest, Wood, and Ancient Man. Interdisciplinaria Archaeologica III(2), 247-255.

Rowley-Conwy, P., 2004. How the West Was Lost. Current Anthropology 45 (Supplement), S83-S113.

Schaffers, A.P., Sýkora, K.V., 2000. Reliability of Ellenberg indicator values for moisture, nitrogen and soil reaction: a comparison with field measurements. Journal of Vegetation Science 11, 225-244.

Schepers, M., 2014. Reconstructing vegetation diversity in coastal landscapes. PhD Thesis, University of Groningen http://dissertations.ub.rug.nl/faculties/arts/2014/m.schepers/ [Accessed 05.01.15].

Schier, W. 2009. Extensiver Brandfeldbau und die Ausbreitung der neolithischen Wirtschaftsweise in Mitteleuropa und Südskandinavien am Ende des 5. Jahrtausends v. Chr. Praehistorische Zeitschrift 84(1), 15-43.

Schier, W., Ehrman, O., Rösch, M., Bogendrieder, A., Hall, M., Herrman. L., Schultz, E., 2013. The economics of Neolithic swidden cultivation: results of an experimental long-term project in Forchtenberg (Baden-Württemberg, Germany). In: Kerig, T., Zimmerman, A. (Eds.), Economic archaeology: from structure to performance. Universitätsforschungen zur prähistorishen Archäologie. Band 237. Verlag Dr. Rudolf Habelt GmbH, Bonn, pp. 97-106. 
Shennan, S., 2008. Population Processes and Their Consequences in Early Neolithic Central Europe. In: Bocquet-Appel, J.-P., Bar-Yosef, O. (Eds.), The Neolithic Demographic Transition and its Consequences. Springer, Netherlands, pp. 315-329.

Shennan, S., 2013. Demographic Continuities and Discontinuities in Neolithic Europe: Evidence, Methods and Implications. Journal of Archaeological Method and Theory 20, 300311.

Shennan, S., 2018. The First Farmers of Europe: An Evolutionary Perspective. Cambridge University Press, Cambridge.

Shennan, S., Downey, S.S., Timpson, A., Edinborough, K., Colledge, S., Kerig, T., Manning, K., Thomas, M.G., 2013. Regional population collapse followed initial agriculture booms in mid-Holocene Europe. Nature Communications 4, Article 2486. DOI: 10.1038/ncomms3486

Shewry, P.R., 2009. Wheat. Journal of Experimental Botany 60(6), 1537-1553.

Shiel, R., 2013. Science and Practice: The Ecology of Manure in Historical Retrospect. In: Jones, R. (Ed.), Manure Matters: Historical, Archaeological and Ethnographic Perspectives. Ashgate Publishing Ltd., Farnham, pp. 13-23.

Sørensen, L., 2014. From hunter to farmer in northern Europe. Migration and adaptation during the Neolithic and Bronze Age. Acta Archaeologica 85(2), 1-305.

Sørensen, L., Karg, S., 2012. The expansion of agrarian societies towards the north - new evidence for agriculture during the Mesolithic/Neolithic transition in Southern Scandinavia. Journal of Archaeological Science 51, 98-114.

Stevens, C.J., Fuller, D.Q, 2012. Did Neolithic farming fail? The case for a Bronze Age agricultural revolution in the British Isles. Antiquity 86, 77-722.

Stevens, C.J., Fuller, D.Q, 2015. Alternative strategies to agriculture: the evidence for climatic shocks and cereal declines during the British Neolithic and Bronze Age (a reply to Bishop). World Archaeology 47(5), 856-875.

Styring, A., Maier, U., Stephan, E., Schlichtherle, H., Bogaard, A. 2016. Cultivation of choice: new insights into farming practices at Neolithic lakeshore sites. Antiquity 90, 95-110.

Timpson, A., Colledge, S., Crema, E., Edinborough, E., Kerig, T., Manning, K., Thomas, M.G., Shennan, S., 2014. Reconstructing regional population fluctuations in the European Neolithic using radiocarbon dates: a new case-study using and improved method. Journal of Archaeological Science 52, 549-557.

Tóth, G., Montanarella, L., Stolbovoy, V., Máté, F., Bódis, K., Jones, A., Panagos, P., van Liedekerke, M., 2008. Soils of the European Union. JRC Scientific and Technical Reports. http://publications.jrc.ec.europa.eu/repository/handle/JRC46573 [Accessed 12.12.2014].

van der Veen, M., 1992. Crop husbandry regimes: an archaeobotanical study of farming in northern England, 1000 BC-AD 500. J.R. Collis Publications, Sheffield. 
van der Veen, M., 2005. Gardens and fields: the intensity and scale of food production. World Archaeology 37(2), 153-163.

van Zeist, W., Palfenier-Vegter, R.M., 1981. Seeds and fruits from the Swifterbant S3 site: final reports on Swifterbant IV. Palaeohistoria 23, 105-168.

Veldkamp, A., 2005. Pedogenesis and soil forming factors. In: Verheye, W.H. (Ed.), Land Use and Land Cover, in Encyclopedia of Life Support Systems (EOLSS), Developed under the Auspices of the UNESCO, Eolss Publishers, Oxford, UK. [http://www.eolss.net]. [Accessed 01.12.14].

Verrill, L., Tipping, R., 2010. Use and abandonment of a Neolithic field system at Belderrig, Co. Mayo, Ireland: Evidence for economic marginality. The Holocene 20(7), 1011-1021.

Warden, L., Moros, M., Neumann, T., Shennan, S., Timpson, A., Manning, K., Sollai, M., Wacker, L., Perner, K., Häusler, K., Leipe, T., Zillén, L., Kotilainen, A., Jansen, E., Schneider, R.R., Oeberst, R., Arz, H., Sinninghe Damste, J.S., 2017. Climate induced human demographic and cultural change in northern Europe during the mid-Holocene. Scientific Reports 7, 15251 DOI:10.1038/s41598-017-14353-5.

Wasylikowa, K., 1981. The role of fossil weeds in the study of former agriculture. Zeistchrift für Archäologie 15, 11-23.

Whitehouse, N.J., Kirleis, W., 2014. The world reshaped: practices and impacts of early agrarian societies. Journal of Archaeological Science 51, 1-11.

Whitehouse, N.J., Schulting, R., McClatchie, M., Barratt, P., McLaughlin, T.R., Bogaard, A., Colledge, S., Marchant, R., Gaffrey, J., Bunting. M.J., 2014. Neolithic agriculture on the European western frontier: the boom and bust of early farming in Ireland. Journal of Archaeological Science 51, 181-205.

Woodbridge, J., Fyfe, R.M., Roberts, N., Downey, S., Edinborough, K., Shennan, S., 2014. The impact of the Neolithic agricultural transition in Britain: a comparison of pollen-based land-cover and archaeological ${ }^{14} \mathrm{C}$ date-inferred population change. Journal of Archaeological Science 51, 216-224.

Zaharieva, M., Monneveux, P., 2014. Cultivated einkorn wheat (Triticum monococcum L. subsp. monococcum): the long life of a founder crop of agriculture. Genetic Resources and Crop Evolution 61, 677-706.

Zohary, D., Hopf, M., Weiss, E., 2012, Domestication of Plants in the Old World. $4^{\text {th }}$ Edition. Oxford University Press, Oxford. 


\section{TABLE CAPTIONS}

Table 1. List of crop types included in the analyses.

Table 2. A: Counts of phases with presence of six crop taxa from 5950 to $4700 \mathrm{cal}$ yr BP for NW Europe; B: Manhattan distance between date bins; C: Z-score of observed distances $\left({ }^{* *} \mathrm{p}<0.05\right)$; D: Crop ubiquity (counts of presence as a percentage of total phases in each date bin); E: Standardised residuals (observed vs expected crop frequencies: ${ }^{*} p<0.1,{ }^{* *} p<0.05$, $* * * \mathrm{p}<0.01)$.

Table 3. A: Number of weed taxa records in each chronological bin from 5950 cal yr BP to $4700 \mathrm{cal}$ yr BP corresponding to vegetation units, perennial and annual weeds, nitrogen, and reaction indicator values; B-E: Manhattan distance matrices and z-values for vegetation units, annual and perennial weeds, nitrogen and reaction indicator values; F: Standardised residuals. Negative results indicate instances where there are fewer observed taxa in that class than predicted; positive more observed taxa in that class than predicted $\left(* \mathrm{p}<0.1,{ }^{*} \mathrm{p}<0.05\right.$, $* * * p<0.01)$; G: Ubiquity calculated as a per cent of total weed records.

Table 4. Soil types included in the analyses. Definitions are taken from the JRC Scientific and Technical Report available via the European Soil Portal website (Tóth et al. 2008; *additional reference is made to: http:/www.fao.org/docrep/003/y1899e/y1899e08.htm). Rankings for suitability as arable soils are made on the basis of the JRC definitions (1: poor, 2: moderate, 3: good).

Table 5. A. Frequency of settlements $(n=278)$ across ranked soil classes (Class $3=$ good, Class 2=moderate, Class 1=poor) from $5950 \mathrm{cal} \mathrm{yr} \mathrm{BP}$ to $4700 \mathrm{cal} \mathrm{yr} \mathrm{BP}$ according to date bins; B. Same data, expressed as percentages of settlements per date bins; C. Z-scores of each date bin, calculated by permutation of soil classes $(* \mathrm{p}<0.1 ; * * \mathrm{p}<0.05)$. Negative results indicate instances where there are fewer observed taxa in that class than predicted; positive more observed taxa in that class than predicted. Bold numbers indicate significant trends over time. 
Oats

Barley

Emmer wheat

Einkorn wheat

Spelt wheat

Free threshing wheat including: Avena sp., Avena sativa

including: Hordeum vulgare (hulled barley), Hordeum vulgare var. nudum (naked barley)

Triticum dicoccum

Triticum monococcum

Triticum spelta

including: Triticum aestivum, Triticum durum

\section{Table 1}


A: Count of phases with crop presence by date

\begin{tabular}{lrrrrrr}
\hline Calibrated Date Range (cal yr BP) & $5950-5700$ & $5700-5450$ & $5450-5200$ & $5200-4950$ & $4950-4700$ & $\begin{array}{r}\text { Crop } \\
\text { Sum }\end{array}$ \\
\hline \hline Barley & 15 & 23 & 28 & 10 & 11 & $\mathbf{8 7}$ \\
Einkorn & 1 & 2 & 17 & 0 & 2 & $\mathbf{2 2}$ \\
Emmer & 17 & 20 & 28 & 7 & 6 & $\mathbf{7 8}$ \\
Free threshing wheat & 4 & 3 & 8 & 1 & 3 & $\mathbf{1 9}$ \\
Oats & 3 & 3 & 0 & 2 & 1 & $\mathbf{9}$ \\
Spelt & 0 & 1 & 2 & 0 & 0 & $\mathbf{3}$ \\
Total Phases & $\mathbf{2 4}$ & $\mathbf{2 7}$ & $\mathbf{3 3}$ & $\mathbf{1 2}$ & $\mathbf{1 4}$ & $\mathbf{1 1 0}$
\end{tabular}

B: Manhattan distance between date bins

\begin{tabular}{lrrrrr}
\hline Calibrated Date Range (cal yr BP) & $5950-5700$ & $5700-5450$ & $5450-5200$ & $5200-4950$ & $4950-4700$ \\
\hline \hline $5950-5700$ & - & & & & \\
$5700-5450$ & 0.10 & - & & & \\
$5450-5200$ & 0.20 & 0.21 & - & & \\
$5200-4950$ & 0.15 & 0.10 & 0.28 & - & - \\
$4950-4700$ & 0.20 & 0.16 & 0.22 & 0.17 & -
\end{tabular}

C: Z-score of observed distances (** $\mathbf{p}<\mathbf{0 . 0 5})$

\begin{tabular}{lrrrrr}
\hline Calibrated Date Range (cal yr BP) & $5950-5700$ & $5700-5450$ & $5450-5200$ & $5200-4950$ & $4950-4700$ \\
\hline \hline $5950-5700$ & - & & & & \\
$5700-5450$ & 0.93 & - & & & \\
$5450-5200$ & -0.76 & -0.86 & - & - \\
$5200-4950$ & 0.11 & 0.92 & $* *-2.01$ & - \\
$4950-4700$ & -0.62 & -0.01 & -0.98 & -0.16 & -
\end{tabular}

D: Crop Ubiquity

\begin{tabular}{lrrrrr}
\hline Calibrated Date Range (cal yr BP) & $5950-5700$ & $5700-5450$ & $5450-5200$ & $5200-4950$ & $4950-4700$ \\
\hline \hline Barley & 62.5 & 85.2 & 84.8 & 83.3 & 78.6 \\
Einkorn & 4.2 & 7.4 & 51.5 & 0.0 & 14.3 \\
Emmer & 70.8 & 74.1 & 84.8 & 58.3 & 42.9 \\
Free threshing wheat & 16.7 & 11.1 & 24.2 & 8.3 & 21.4 \\
Oats & 12.5 & 11.1 & 0.0 & 16.7 & 7.1 \\
Spelt & 0.0 & 3.7 & 6.1 & 0.0 & 0.0
\end{tabular}

E. Standardised Residuals

\begin{tabular}{lrrrrr}
\hline Calibrated Date Range (cal yr BP) & $5950-5700$ & $5700-5450$ & $5450-5200$ & $5200-4950$ & $4950-4700$ \\
\hline \hline Barley & -0.26 & 0.52 & -0.9 & 0.76 & 0.57 \\
Einkorn & -1.49 & -1.46 & $* * * 2.91$ & -1.43 & -0.28 \\
Emmer & 0.74 & 0.34 & -0.28 & -0.07 & -0.75 \\
Free threshing wheat & 0.3 & -0.73 & 0.3 & -0.56 & $* * 2.14$ \\
Oats & 0.96 & 0.53 & $*-1.85$ & 1.23 & -0.67 \\
Spelt & -0.74 & 0.38 & 0.78 & -0.54 & -0.56
\end{tabular}

Table 2 
A. Number of weed taxa records in each chronological bin

\begin{tabular}{|c|c|c|c|c|c|c|}
\hline Calibrated Date Range (cal yr BP) & $5950-5700$ & $5700-5450$ & $5450-5200$ & $5200-4950$ & $4950-4700$ & Sum \\
\hline Total number of weed taxa records & 24 & 108 & 71 & 54 & 77 & 334 \\
\hline Vegetation Unit U3 & 11 & 55 & 50 & 20 & 21 & 157 \\
\hline Vegetation Unit U5 & 5 & 23 & 9 & 25 & 30 & 92 \\
\hline Perennial Weeds & 12 & 46 & 19 & 34 & 44 & 155 \\
\hline Annual Weeds & 11 & 59 & 51 & 20 & 30 & 171 \\
\hline Nitrogen Indicator (Low) & 6 & 25 & 13 & 19 & 33 & 96 \\
\hline Nitrogen Indicator (High) & 12 & 52 & 39 & 15 & 31 & 149 \\
\hline Reaction Value (Low - acidic) & 2 & 15 & 9 & 14 & 25 & 65 \\
\hline Reaction Value (High- alkali) & 9 & 33 & 24 & 10 & 21 & 97 \\
\hline
\end{tabular}

B: Manhattan distance matrix for Vegetation Units

\begin{tabular}{lrrrrr}
\hline Calibrated Date Range (cal yr BP) & $5950-5700$ & $5700-5450$ & $5450-5200$ & $5200-4950$ & $4950-4700$ \\
\hline \hline $5950-5700$ & - & & & & \\
$5700-5450$ & 0.02 & - & & & \\
$5450-5200$ & 0.16 & 0.14 & - & \\
$5200-4950$ & 0.24 & 0.26 & 0.40 & - \\
$4950-4700$ & 0.28 & 0.29 & 0.44 & 0.03 & -
\end{tabular}

B: Z-values for Vegetation Units

\begin{tabular}{lrrrrr}
\hline Calibrated Date Range (cal yr BP) & $5950-5700$ & $5700-5450$ & $5450-5200$ & $5200-4950$ & $4950-4700$ \\
\hline \hline $5950-5700$ & - & & & & \\
$5700-5450$ & 1.15 & - & & & \\
$5450-5200$ & -0.70 & -0.48 & - & \\
$5200-4950$ & $*-1.79$ & $* *-2.02$ & $* * *-3.88$ & - \\
$4950-4700$ & $* *-2.22$ & $* *-2.45$ & $* * *-4.31$ & 0.96 & -
\end{tabular}

C: Manhattan distance matrix for Annual and Perennial Weeds

\begin{tabular}{lrrrrr}
\hline Calibrated Date Range (cal yr BP) & $5950-5700$ & $5700-5450$ & $5450-5200$ & $5200-4950$ & $4950-4700$ \\
\hline \hline $5950-5700$ & - & & & & \\
$5700-5450$ & 0.08 & - & & & \\
$5450-5200$ & 0.25 & 0.17 & - & \\
$5200-4950$ & 0.11 & 0.19 & 0.36 & - \\
$4950-4700$ & 0.07 & 0.16 & 0.32 & 0.04
\end{tabular}

C: Z-values for Annual and Perennial Weeds

\begin{tabular}{lrrrrr}
\hline Calibrated Date Range (cal yr BP) & $5950-5700$ & $5700-5450$ & $5450-5200$ & $5200-4950$ & $4950-4700$ \\
\hline \hline $5950-5700$ & - & & & & \\
$5700-5450$ & 0.09 & - & & & \\
$5450-5200$ & $* *-2.41$ & -1.16 & - & \\
$5200-4950$ & -0.27 & -1.53 & $* * *-4.02$ & - \\
$4950-4700$ & 0.25 & -1.01 & $* * *-3.50$ & 0.82 & -
\end{tabular}


D: Manhattan distance matrix for Nitrogen Indicator Values

\begin{tabular}{|c|c|c|c|c|c|}
\hline Calibrated Date Range (cal yr BP) & $5950-5700$ & $5700-5450$ & $5450-5200$ & $5200-4950$ & $4950-4700$ \\
\hline $5950-5700$ & - & & & & \\
\hline $5700-5450$ & 0.01 & - & & & \\
\hline $5450-5200$ & 0.08 & 0.07 & - & & \\
\hline $5200-4950$ & 0.23 & 0.23 & 0.31 & - & \\
\hline $4950-4700$ & 0.18 & 0.19 & 0.27 & 0.04 & - \\
\hline \multicolumn{6}{|c|}{ D: Z-values for Nitrogen Indicator Values } \\
\hline Calibrated Date Range (cal yr BP) & $5950-5700$ & $5700-5450$ & $5450-5200$ & $5200-4950$ & 4950-4700 \\
\hline $5950-5700$ & - & & & & \\
\hline $5700-5450$ & 1.20 & - & & & \\
\hline $5450-5200$ & 0.20 & 0.30 & - & & \\
\hline $5200-4950$ & -1.60 & $*_{-}-1.70$ & $* * *-2.70$ & - & \\
\hline $4950-4700$ & -1.10 & -1.20 & $* *-2.10$ & 0.80 & \\
\hline
\end{tabular}

E: Manhattan distance matrix for Reaction Indicator Values

\begin{tabular}{lrrrrr}
\hline Calibrated Date Range (CAL YR BP) & $5950-5700$ & $5700-5450$ & $5450-5200$ & $5200-4950$ & $4950-4700$ \\
\hline \hline $5950-5700$ & - & & & & \\
$5700-5450$ & 0.13 & - & & & \\
$5450-5200$ & 0.09 & 0.04 & - & & \\
$5200-4950$ & 0.40 & 0.27 & 0.31 & - \\
$4950-4700$ & 0.36 & 0.23 & 0.27 & 0.04
\end{tabular}

E: Z-values for Reaction Indicator Values

\begin{tabular}{|c|c|c|c|c|c|}
\hline Calibrated Date Range (cal yr BP) & $5950-5700$ & $5700-5450$ & $5450-5200$ & $5200-4950$ & $4950-4700$ \\
\hline $5950-5700$ & - & & & & \\
\hline $5700-5450$ & -0.62 & - & & & \\
\hline $5450-5200$ & 0.34 & 0.88 & - & & \\
\hline $5200-4950$ & $* * *-2.88$ & -1.52 & $*-1.93$ & - & \\
\hline $4950-4700$ & $* *-2.46$ & -1.10 & -1.52 & 0.88 & - \\
\hline \multicolumn{6}{|l|}{ F. Standardised residuals } \\
\hline Calibrated Date Range (cal yr BP) & $5950-5700$ & $5700-5450$ & $5450-5200$ & $5200-4950$ & $4950-4700$ \\
\hline Vegetation Unit U3 & 0.30 & 0.80 & $* * 2.09$ & -1.56 & $* *-1.96$ \\
\hline Vegetation Unit U5 & -0.39 & -1.05 & $* * *-2.74$ & $* 2.02$ & $* * 2.53$ \\
\hline Perennial Weeds & 0.31 & -0.56 & $* *-2.48$ & 1.60 & 1.43 \\
\hline Annual Weeds & -0.30 & 0.53 & $* * 2.37$ & -1.54 & -1.37 \\
\hline Nitrogen Indicator (Low) & -0.35 & -0.93 & $*-1.65$ & 1.58 & 1.61 \\
\hline Nitrogen Indicator (High) & 0.27 & 0.74 & 1.33 & -1.26 & -1.29 \\
\hline Reaction Value (Low - acidic) & -1.15 & -0.99 & -1.17 & 1.39 & 1.56 \\
\hline Reaction Value (High- alkali) & 0.94 & 0.82 & 0.95 & -1.14 & 1.56 \\
\hline
\end{tabular}


G. Ubiquity

Calibrated Date Range (cal yr BP)

5950-5700

5700-5450

5450-5200

$5200-4950$

4950-4700

Vegetation Unit U3

45.8

50.9

70.4

37.0

27.3

Vegetation Unit U5

20.8

21.3

12.7

46.3

39.0

Perennial Weeds

50.0

42.6

26.8

63.0

57.1

Annual Weeds

45.8

54.6

71.8

37.0

39.0

Nitrogen Indicator (Low)

25.0

23.1

18.3

35.2

42.9

Nitrogen Indicator (High)

50.0

48.1

54.9

27.8

40.3

Reaction Value (Low - acidic)

8.3

13.9

12.7

25.9

32.5

Reaction Value (High- alkali)

37.5

30.6

33.8

18.5

27.3

\section{Table 3}


Low nutrient status, acidity, tillage and drainage problems are serious limitations for the use of Albeluvisols, which are extended by short growing

The properties of the organic soil material (botanical composition, stratification, degree of decomposition, packing density, wood content, mineral admixtures, etc.) and the type of peat bog (basin peat, raised bog, etc.) determine the management requirements and use possibilities of Histosols. Northern Histosols are of little use for agriculture but they are part of a unique ecosystem and a habitat for many plant and animal species.

Leptosols are generally well-drained soils; however they have very few other favorable characteristics for agricultural utilization. The suitability of

leptosol

planosol Leptosols in most areas is limited to forestry.

\section{podzol}

Most Planosols are poor soils and are therefore not used as cropland but utilized for extensive grazing and forestry.

Due to the limiting climatic conditions Zonal Podzols generally have low suitability for agricultural production. Azonal podzols can be utilized for agricultural use after amelioration (e.g deep ploughing, liming).

Limiting factors for the development of Regosols range from low soil temperatures and prolonged dryness to characteristics of the parent material or erosion. The options for land use and management of these soils vary widely. Some Regosols are used for irrigated farming but generally they are kept for low volume grazing. In mountain areas Regosols are mostly forested.

regosol

Land use options on Solonchak soils are largely limited by the salt content. The salts magnify drought stress because dissolved electrolytes create an osmotic potential that affects water uptake by plants. A possible way of reclamation is to flush salts out from the soil. However, most Solonchaks can solonchak be used for extensive grazing.

Arenosols are easily erodable with slow weathering rate, low water and nutrient holding capacity and low base saturation. However, the high permeability and easy workability qualifies these soils for high agricultural potential depending on the availability of water and fertilization. Their characteristics and fertility depend on the nature and sequence of the sediments and length of periods of soil formation after or between flood events.

\section{arenosol}

fluvisol

gleysol

The main obstacle to utilisation of Gleysols is the necessity to install a drainage system, designed to either lower the groundwater table, or intercept seepage or surface runoff water. Adequately drained Gleysols can be used for arable cropping, dairy farming or horticulture.

Dry Vertisols can be very hard, while wet Vertisols are very plastic and sticky. The agricultural use of Vertisols is depending on their physical characteristics, and ranges from very extensive use through smallholder post-rainy season crop production to small-scale and large-scale irrigated agriculture.

vertisol

The average organic matter content of the surface horizon is about $8 \%$ but some varieties may contain as much as $30 \%$ organic matter. The surface horizon is very porous and the good aggregate stability of Andosols and their high permeability to water make these soils both fertile and relatively andosol

cambisol resion.

[relative suitability for arable farming not given in EU report]; from alternative source*: By and large, Cambisols make good agricultural land and are chernozem

luvisol

phaeozem page

reference

ranking

14

1

\begin{tabular}{|c|c|}
\hline 34 & 1 \\
\hline 38 & 1 \\
\hline 44 & 1 \\
\hline 46 & 1 \\
\hline 48 & 1 \\
\hline 50 & 1 \\
\hline 20 & 2 \\
\hline 28 & 2 \\
\hline 30 & 2 \\
\hline 56 & 2 \\
\hline 16 & 3 \\
\hline- & 3 \\
\hline 26 & 3 \\
\hline 40 & 3 \\
\hline 42 & 3 \\
\hline
\end{tabular}

\section{Table 4}


A. Count by date of settlement sites classified according to soil class

\begin{tabular}{lrrrrrr} 
Calibrated Date Range (cal yr BP) & $5950-5700$ & $5700-5450$ & $5450-5200$ & $5200-4950$ & $4950-4700$ & Sum \\
\hline \hline Class 1 & 13 & 18 & 14 & 12 & 13 & $\mathbf{7 1}$ \\
Class 2 & 13 & 18 & 8 & 7 & 8 & $\mathbf{5 4}$ \\
Class 3 & 31 & 49 & 30 & 20 & 24 & $\mathbf{1 5 4}$ \\
Total sites & $\mathbf{5 6}$ & $\mathbf{8 6}$ & $\mathbf{5 2}$ & $\mathbf{3 9}$ & $\mathbf{4 6}$ & $\mathbf{2 7 8}$
\end{tabular}

B. Percent by date of settlement sites classified according to soil class

\begin{tabular}{lrrrrr}
\hline Calibrated Date Range (cal yr BP) & $5950-5700$ & $5700-5450$ & $5450-5200$ & $5200-4950$ & $4950-4700$ \\
\hline \hline Class 1 & 23 & 21 & 26 & 32 & 29 \\
Class 2 & 23 & 22 & 16 & 17 & 17 \\
Class 3 & 54 & 57 & 58 & 51 & 53
\end{tabular}

C. Z-scores

\begin{tabular}{lrrrrr}
\hline Calibrated Date Range (cal yr BP) & $5950-5700$ & $5700-5450$ & $5450-5200$ & $5200-4950$ & $4950-4700$ \\
\hline \hline Class 1 & -0.71 & $*-1.71$ & 0.18 & 1.64 & 0.98 \\
Class 2 & 0.93 & 0.86 & $* *-2.06$ & -1.50 & -1.37 \\
Class 3 & 0.50 & $* 1.72$ & 1.31 & -1.27 & -0.38
\end{tabular}

Table 5 


\section{FIGURE CAPTIONS}

Figure 1. Summed calibrated date probability distribution inferred population density change 7950-3950 cal yr BP for NW Europe (data source: Manning et al. 2015); statistically significant positive and negative deviations from a null model of exponential growth are indicated in red and blue respectively; dotted line shows the fitted null exponential model.

Figure 2. Map showing location of sites with archaeobotanical records included in the study. 1: Abingdon; 2: Albersdorf-Brutkamp LA 5; 3: Achnasavil; 4: Alt Chrysal; 5: Ballinglanna North; 6: Ballybannon; 7: Ballinaspig More; 8: Ballintaggart; 9: Boghead; 10: Bromfield; 11: Briar Hill; 12: Bharpa Carinish; 13: Barrow Hills; 14: Barnhouse; 15: Balbridie; 16: Caythorpe; 17: Caw; 18: Caherabbey; 19: Cherryville; 20: Claish Farm; 21: Clowanstown; 22: Cowie Road; 23: Coneybury 'Anomaly'; 24: Carzield; 25: Deer's Den; 26: Down Farm; 27: Dösjöbro; 28: Eisendorf; 29: Enagh; 30: Flögeln; 31: Flagstones; 32: Gortaroe; 33:

Gortore 1; 34: Granny; 35: Gransha; 36: Haggardstown; 37: Hazendonk; 37: Hazendonk; 38: Hereford - Asda site; 39: Hekelingen 3; 40: Hemmingstedt LA2; 41: Hambledon Hill; 42: Hjulberga; 43: Hazleton North; 44: Harristown Big; 45: Ibister 'Tomb of the Eagles'; 46: W59 King Barrow Ridge; 47: Kerloge; 48: Kilsheelan; 49: Kinbeachie; 50: Knap of Howar; 51: Karlsfält; 53: Lidsø; 54: Lønt; 55: Lismore Fields; 56: Magheraboy; 57: Maiden Castle; 58: Månasken; 59: Marton-le-Moor; 60: Monanny; 61: Mogetorp; 62: Moel y Gerddi; 63: Newrath 35; 64: Newrath 37; 65: Oldenburg Dannau LA191; 66: Oldenburg Dannau LA77; 67: Østerskov Å; 68: Pool; 69: Piledal; 70: Potlock cursus monument; 71: Pepperhill; 72: Rastorf LA6c; 73: 3017 Reading Business park; 74: Rijswijk-Ypenburg; 75: Russellstown; 76: Rowden; 77: Scord of Brouster; 78: Schipluiden-Harnaschpolder; 79: Bad Segeberg LA 93; 80: Spodsbjerg; 81: Spong Hill; 82: Sarup; 83: Stora Råby; 84: Stones of Stenness; 85: Stengade; 86: Sturup; 87: Svenstorp; 88: Tankardstown Site; 89: Thirlings; 90: Tofts Ness; 91: The Stumble; 92: Tullahedy; 93: Visborg; 94: Windmill Hill; 95: Whitesheet Down; 96: Windmill Hill - external features; 97: West Kennett Palisade; 98: Wangels LA505; 99: Wateringen 4; 100: Whitton Hill.

Figure 3. Trends in crop use over time as represented by changes in ubiquity scores (Table 2B) according to date bin for the three most commonly occurring crops: barley, emmer and einkorn (solid line shows population density overlay for y-axis only, see Fig. 1 for values).

Figure 4. Trends over time in vegetation units, nitrogen and reaction indicator values and perennial and annual weeds as represented by ubiquity scores of weed species according to date bin as provided in Table 3B (dashed line shows population density overlay for y-axis only, see Fig. 1 for values).

Figure 5. Trends over time in site locations according to ranked soil classes based on the percentage of settlement sites according to date bin as provided in Table 5B (solid line shows population density overlay for y-axis only, see Fig. 1 for values).

Figure 6. Comparative chronologies for NW European Neolithic periods and cultures between 6000 and 4000 cal yr BP (references for date ranges: Raemakers and Paulien de Roever, 2010; Manning et al., 2014; Whitehouse et al., 2014). 
Figure 1

NW Europe Samples N=5992, bins N=2577, Sites N=1857, $P$-value $<0.0001$

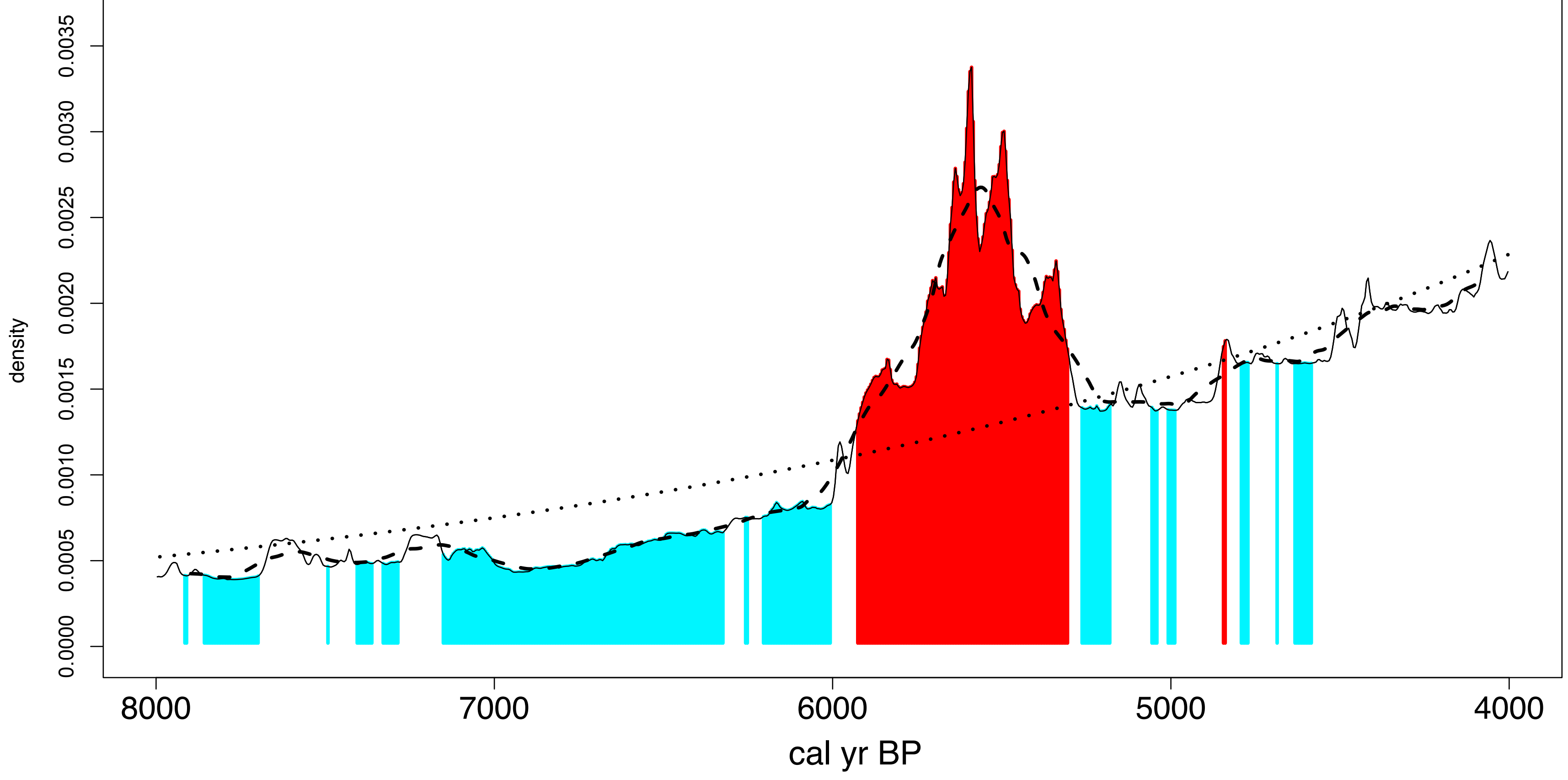




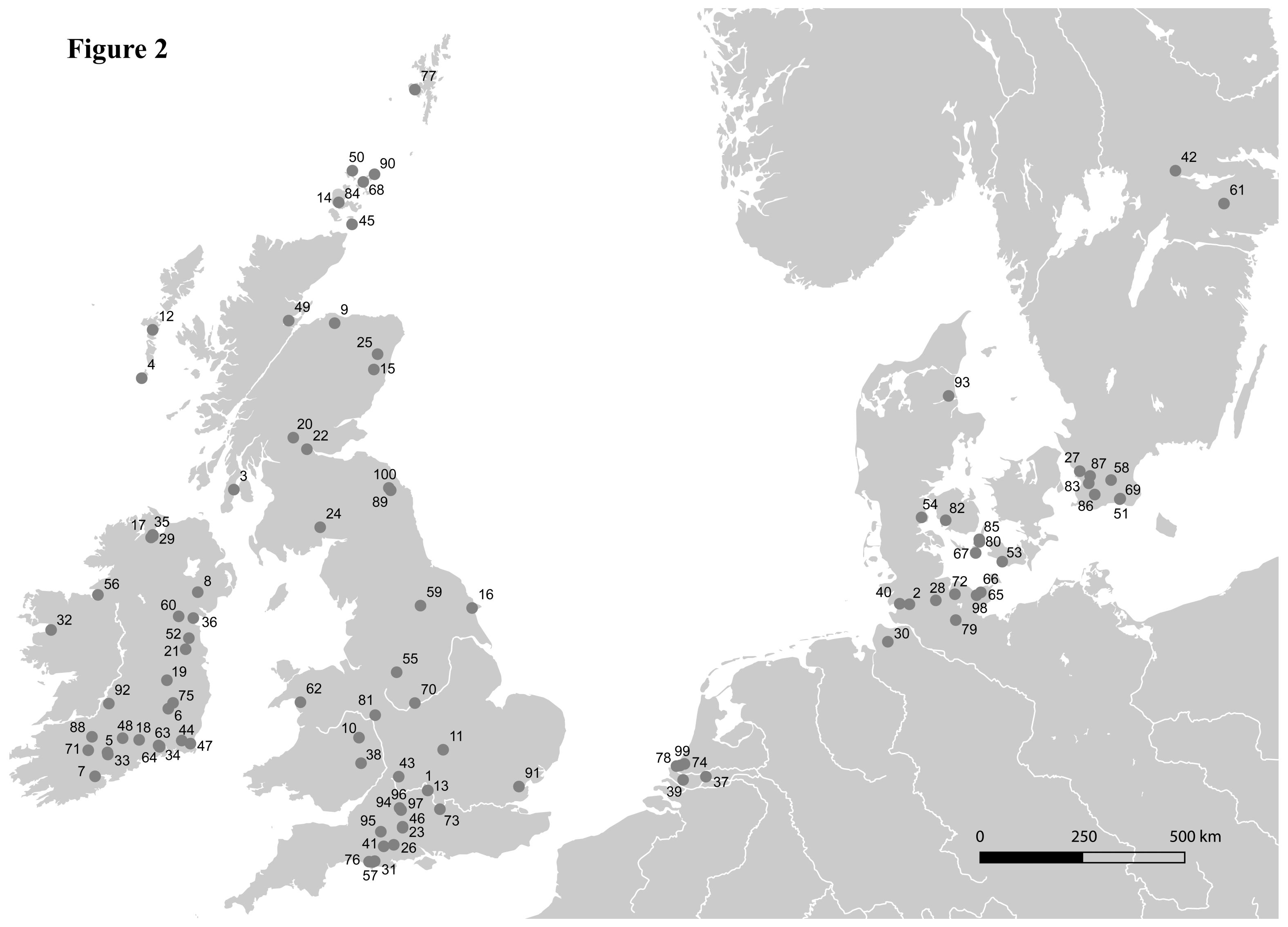




\section{Figure 3}
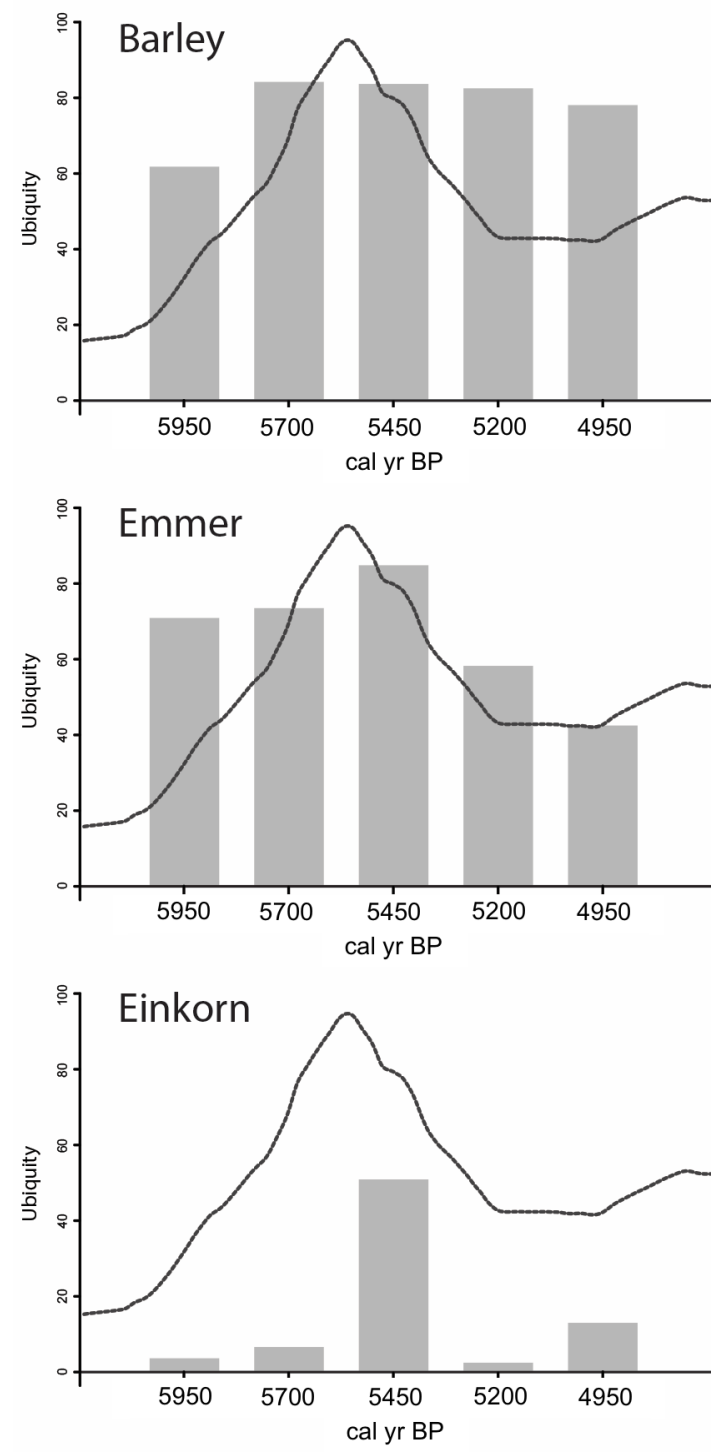

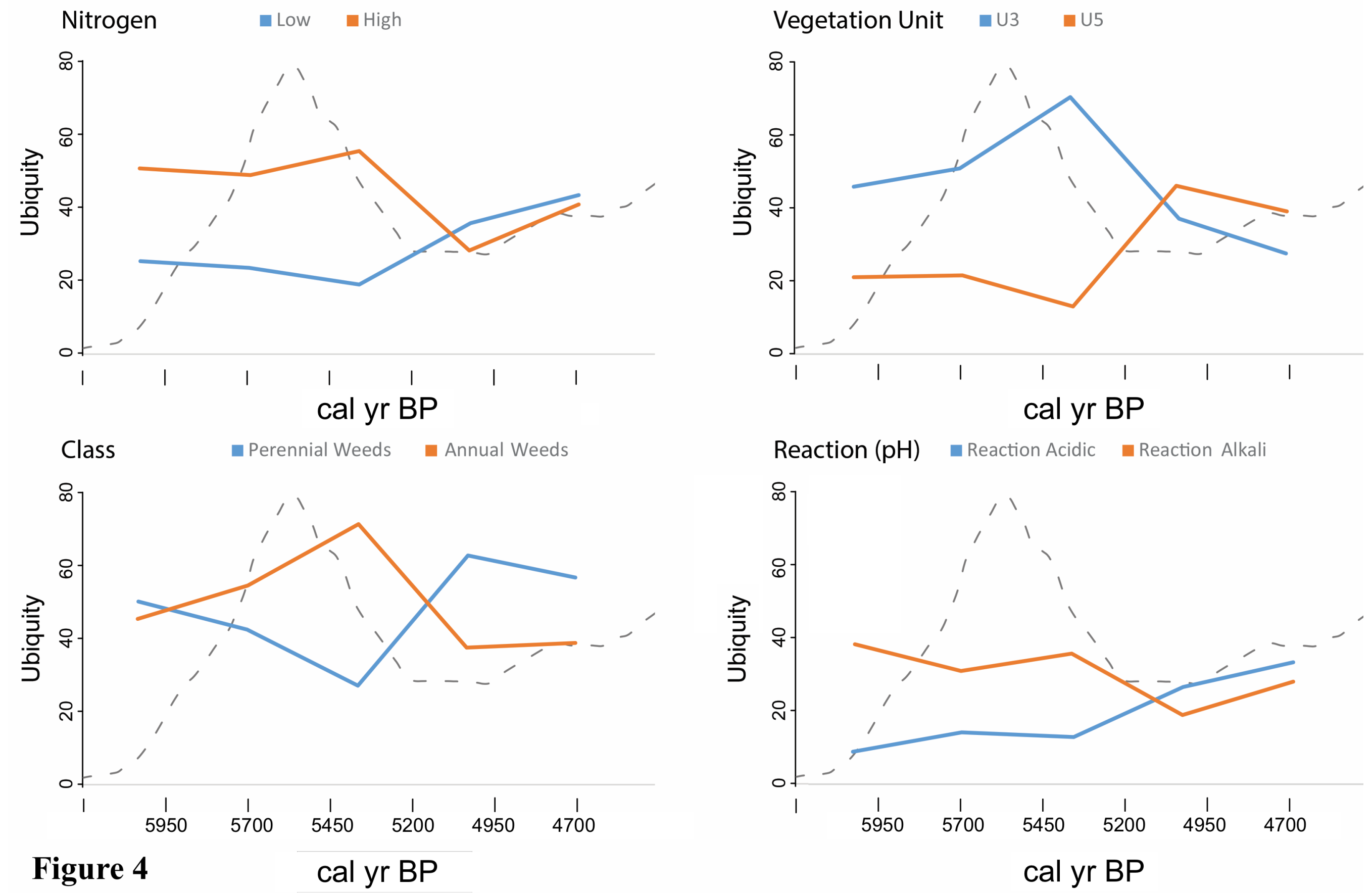
Figure 5

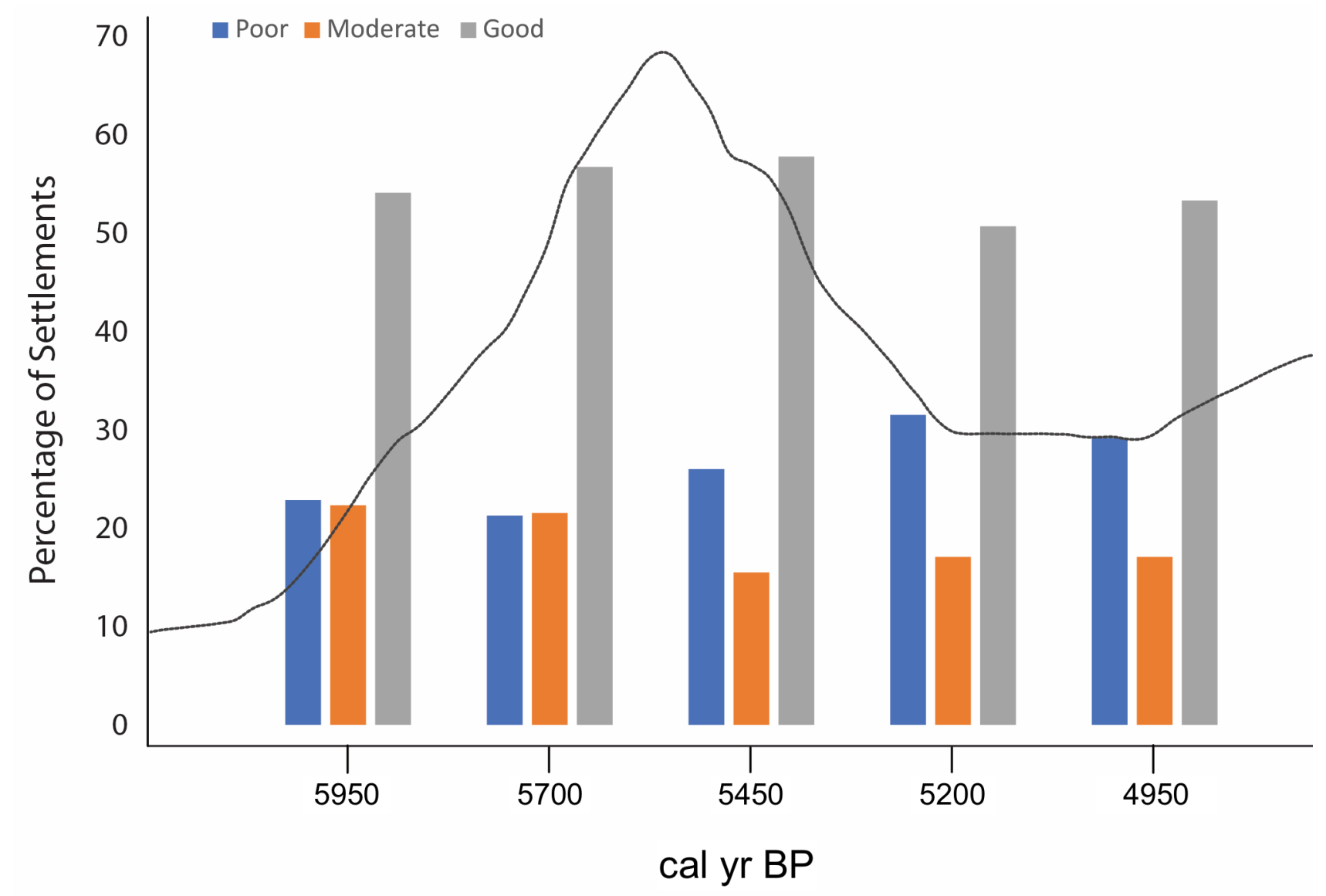


Figure 6

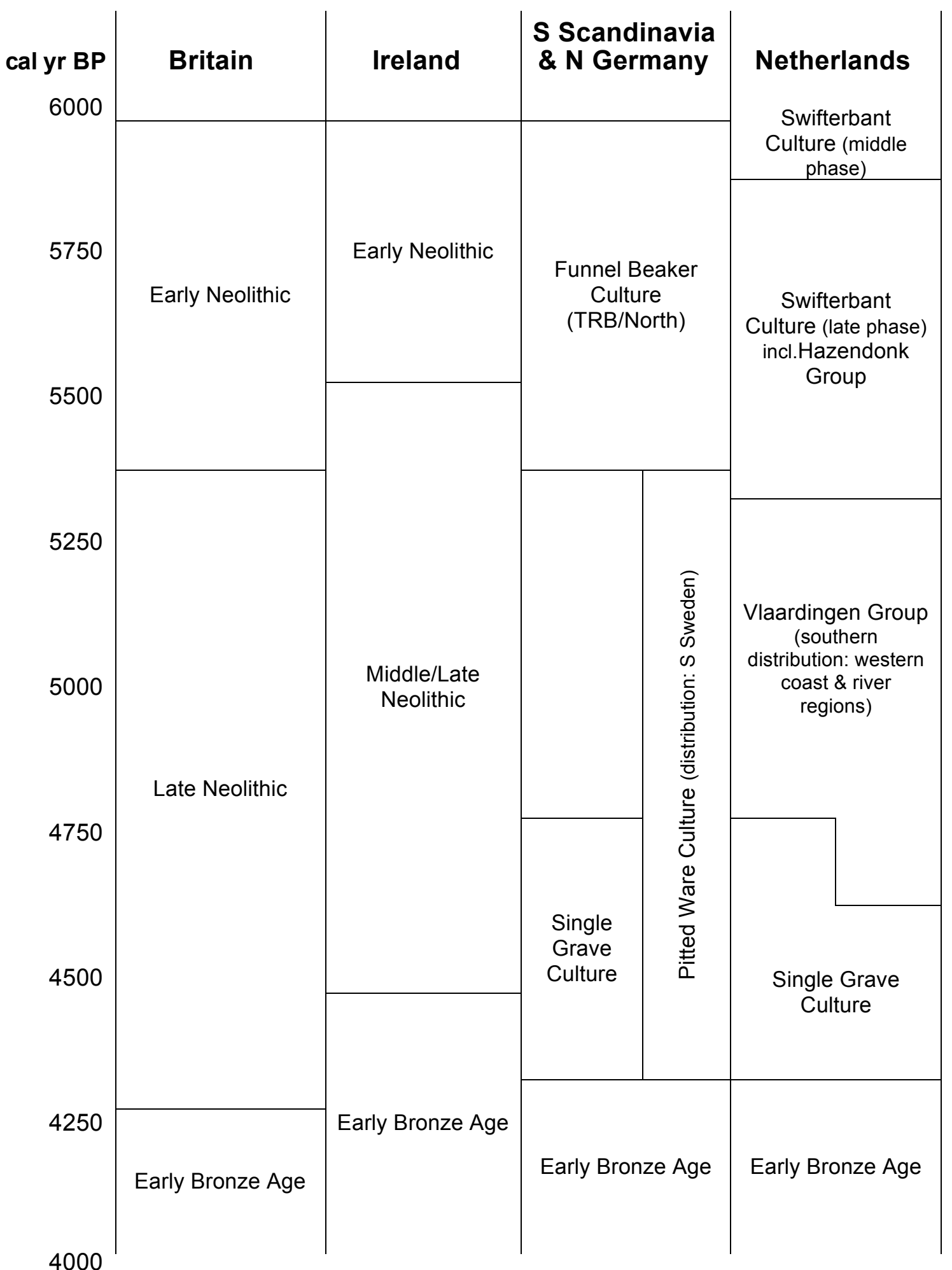

